\title{
Neuronal impairment following chronic Toxoplasma gondii infection is aggravated by intestinal nematode challenge in an IFN- $\gamma$-dependent manner
}

Timothy French ${ }^{1}$, Henning Peter Düsedau', Johannes Steffen ${ }^{1}$, Aindrila Biswas ${ }^{1}$, Norus Ahmed ${ }^{3}$, Susanne Hartmann ${ }^{3}$, Thomas Schüler ${ }^{2}$, Björn H. Schott ${ }^{4,5,6}$ and Ildiko Rita Dunay ${ }^{1,5^{*}}$

\begin{abstract}
Background: It has become increasingly evident that the immune and nervous systems are closely intertwined, relying on one another during regular homeostatic conditions. Prolonged states of imbalance between neural and immune homeostasis, such as chronic neuroinflammation, are associated with a higher risk for neural damage. Toxoplasma gondii is a highly successful neurotropic parasite causing persistent subclinical neuroinflammation, which is associated with psychiatric and neurodegenerative disorders. Little is known, however, by what means neuroinflammation and the associated neural impairment can be modulated by peripheral inflammatory processes.
\end{abstract}

Methods: Expression of immune and synapse-associated genes was assessed via quantitative real-time PCR to investigate how T. gondii infection-induced chronic neuroinflammation and associated neuronal alterations can be reshaped by a subsequent acute intestinal nematode co-infection. Immune cell subsets were characterized via flow cytometry in the brain of infected mice. Sulfadiazine and interferon- $\gamma$-neutralizing antibody were applied to subdue neuroinflammation.

Results: Neuroinflammation induced by T. gondii infection of mice was associated with increased microglia activation, recruitment of immune cells into the brain exhibiting Th1 effector functions, and enhanced production of Th1 and proinflammatory molecules (IFN- $\gamma$, iNOS, IL-12, TNF, IL-6, and IL-1ß) following co-infection with Heligmosomoides polygyrus. The accelerated cerebral Th1 immune response resulted in enhanced T. gondii removal but exacerbated the inflammation-related decrease of synapse-associated gene expression. Synaptic proteins EAAT2 and GABA $a 1$, which are involved in the excitation/inhibition balance in the CNS, were affected in particular. These synaptic alterations were partially recovered by reducing neuroinflammation indirectly via antiparasitic treatment and especially by application of IFN- $\gamma$-neutralizing antibody. Impaired iNOS expression following IFN- $\gamma$ neutralization directly affected EAAT2 and GABA ${ }_{A} \mathrm{a} 1$ signaling, thus contributing to the microglial regulation of neurons. Besides, reduced CD36, TREM2, and C1qa gene expression points toward inflammation induced synaptic pruning as a fundamental mechanism.

Conclusion: Our results suggest that neuroimmune responses following chronic T. gondii infection can be modulated by acute enteric nematode co-infection. While consecutive co-infection promotes parasite elimination in the CNS, it also adversely affects gene expression of synaptic proteins, via an IFN- $\gamma$-dependent manner.

Keywords: Toxoplasma gondii, Heligmosomoides polygyrus, Co-infection, Immunomodulation, Neuroinflammation

\footnotetext{
*Correspondence: ildikodunay@gmail.com

${ }^{1}$ Institute of Inflammation and Neurodegeneration, Medizinische Fakultät,

Otto-von-Guericke-University Magdeburg, Leipziger Straße 44, 39120

Magdeburg, Germany

${ }^{5}$ Center for Behavioral Brain Sciences, Magdeburg, Germany

Full list of author information is available at the end of the article
}

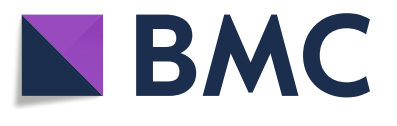

(c) The Author(s). 2019 Open Access This article is distributed under the terms of the Creative Commons Attribution 4.0 International License (http://creativecommons.org/licenses/by/4.0/), which permits unrestricted use, distribution, and reproduction in any medium, provided you give appropriate credit to the original author(s) and the source, provide a link to the Creative Commons license, and indicate if changes were made. The Creative Commons Public Domain Dedication waiver (http://creativecommons.org/publicdomain/zero/1.0/) applies to the data made available in this article, unless otherwise stated. 


\section{Background}

Immune activity in the central nervous system (CNS) historically has been thought to almost invariably reflect pathological processes [1-3]. However, inflammation is an integral component of neurobiological processes supporting tissue repair, synaptic pruning, pathogen removal, and inflammation resolution to maintain homeostasis [4]. Still, there is the physical segregation of the nervous and immune systems via the blood-brain barrier (BBB), separating the CNS from the peripheral cytokine milieu and allows for more controlled neuro-immune activity. However, when the $\mathrm{BBB}$ is compromised, as in neuroinflammation, the brain parenchyma becomes threatened as there is an increased activation of both resident and recruited immune activity [5]. Interferon- $\gamma$ (IFN- $\gamma$ ), a crucial type 1 cytokine, for example, has been shown to modulate the activity of the principal inhibitory neurotransmitter gammaaminobutyric acid (GABA), thereby affecting neuronal connectivity and social behavior [6]. Pro-inflammatory cytokines such as tumor necrosis factor (TNF), interleukin (IL)-6, or IL-1 $\beta$ have been linked to neuronal cell death via both apoptosis and necrosis and to cognitive and motor dysfunction [7, 8]. Furthermore, downregulation of pro-inflammatory myeloid cell activity via the type 2 cytokine IL-4 produced by $\mathrm{T}$ cells has been associated with increased release of brain-derived neurotrophic factor (BDNF) and reversal of memory impairment [9]. Conversely, microglia, the resident innate immune cells of the CNS, have been shown to express receptors for multiple neurotransmitters including GABA, glutamate, or dopamine [10-13]. These findings highlight a rather pleiotropic role of the respective proteins in normal physiology, with their functions depending on their location. In chronic neuroinflammation, there is a prolonged activated and recruited immune presence in the CNS and neural and immune functions can become dysbalanced, increasing the risk for secondary neural damage. This is evident in the strong association of chronic neuroinflammation with neurodegenerative diseases such as Alzheimer's disease (AD) [14], Parkinson's disease (PD) [15], amyotropic lateral sclerosis (ALS) [16], and the profound inflammation-related neural damage found in multiple sclerosis (MS) [17].

Invasion of the CNS by neurotropic pathogens is a common cause of chronic neuroinflammation [18]. Toxoplasma gondii ( $T$. gondii) preferentially infects neurons where it forms cysts that remain for the lifetime of the host causing persistent subclinical neuroinflammation $[19,20]$. The conversion of fastreplicating tachyzoites to slow-replicating bradyzoites and the subsequent formation of a cyst wall are induced by the host's adaptive immune response. T cells are critical in preventing the reactivation of bradyzoite-filled cysts, as evident in the prolonged low-grade cerebral inflammation to control chronic infection seen in immunocompetent hosts [21, 22]. Neuroinflammation is initially facilitated when resident microglia and astrocytes first encounter the invading parasites, which leads to the release of chemokines and pro-inflammatory mediators (i.e., TNF, IL-6, or IL-1 $\beta$ ) followed by recruitment of peripheral myeloid and lymphoid cells [23-25]. Myeloid cells support chronic neuroinflammation by their capacity to produce pro-inflammatory cytokines such as IL12 , which is crucial in maintaining the production of IFN- $\gamma$. Produced primarily by $\mathrm{CD}^{+}$and $\mathrm{CD}^{+} \mathrm{T}$ cells as well as innate lymphoid cells $[26,27]$, IFN- $\gamma$ is an essential factor in host protection against the parasite, as it triggers multiple immune cell mechanisms leading to the elimination of the parasite [28]. Moreover, IFN- $\gamma$ can activate the choroid plexus endothelium, thereby aiding the migration of leukocytes into the CNS parenchyma [29, 30].

$T$. gondii infection has been shown to alter behavior in rodents [29], and in humans, seropositive individuals have been shown to exhibit subclinical behavioral alterations as well as an increased risk for neuropsychiatric disorders [30] such as PD [31], AD [32], or schizophrenia [33]. Conclusively, a recent large-scale study provided compelling evidence for the association between latent $T$. gondii infection and schizophrenia in humans [18]. Distinctly, the immune response to $T$. gondii and the neuropathological mechanisms of these disorders overlap by involving the same cell types and, at least in part, the same molecules. We have previously demonstrated that chronic $T$. gondii infection leads to a loss of structural complexity of axons and dendrites, primarily in the neocortex and hippocampus [34]. Moreover, we have recently shown that the synaptic protein composition was altered, in particular, with a downregulation of components of glutamatergic signaling as a consequence of the inflammatory milieu induced by chronic infection [35].

A common clinical approach for treating neuroinflammatory disorders has been the application of immunosuppressive or anti-inflammatory drugs, to slow down disease progression, but side effects are often severe $[36,37]$. In the case of infections underlying neuroinflammation, as in cerebral toxoplasmosis, this is particularly dangerous as immunocompromised individuals are at risk for reactivation of life-threatening acute Toxoplasma encephalitis (TE) [38, 39]. More recently, immunomodulatory approaches are being applied to modify the immune response without removing the homeostatic functions of cells 
such as tissue maintenance and repair [40-42]. Helminths administered as immunotherapy have gained significant attention, where live parasitic worms or worm-derived molecules are applied as treatment of chronic inflammatory diseases [43-45]. By taking advantage of helminths' natural abilities to create an anti-inflammatory environment, helminth infection and helminth-derived molecules have the potential to beneficially modulate immune responses to potentially pre-existing diseases. Helminth immunomodulation has already shown success in human models of inflammatory bowel diseases $[46,47]$ and multiple sclerosis (MS) [48-50] as well as murine models of allergic airway hyperreactivity [51-53] rheumatoid arthritis (RA), type 1 diabetes, and experimental autoimmune encephalomyelitis (EAE) $[44,54,55]$. Helminths primarily achieve this immunomodulation via induction of regulatory circuits. In general, helminth infections stimulate the release of IL-4, IL-5, IL-10, and IL-13, which shifts T cell responses towards a Th2 response [56]. Regulatory $\mathrm{T}$ cells (Tregs) as well as regulatory macrophages are also stimulated, leading to increased production of anti-inflammatory cytokines IL-10 and transforming growth factor beta (TGF- $\beta$ ), which corroborate the helminths' induced anti-inflammatory environment [57]. Scientific interest continues to grow around helminth-dependent immune modulation, especially in response to the increasing incidence of allergies and auto-immune diseases [58, 59]. However, there is insufficient knowledge about the potential effects of peripheral helminth infections on concurrent inflammatory processes in the CNS.

In the present study, we aimed to elucidate how immunological and neural sequelae of $T$. gondii-induced neuroinflammation are altered by a concomitant intestinal helminth infection and resulting immunomodulation. To this end, we administered the strictly enteric intestinal nematode Heligmosomoides polygyrus ( $H$. polygyrus) to mice previously infected with $T$. gondii. $H$. polygyrus infection is known to lead to a strong induction and systemic dissemination of Th2-type responses during the acute phase of infection [60, 61]. Our data revealed that a co-infection of $T$. gondii-infected mice with $H$. polygyrus induced an increase of the recruitment of Ly6 $\mathrm{C}^{\mathrm{hi}}$ inflammatory monocytes and subsequent increase in the Th1 immune response of resident and recruited immune cells, characterized by IFN- $\gamma$, IL-12, iNOS, and MHC II expression. This upregulation of the Th1 response and inflammatory cell recruitment ultimately led to a significant reduction of the parasite burden in co-infected mice. However, this was accompanied by a reduction in neural markers, as determined by synaptic gene expression changes. Notably, the synaptic alterations were partially recovered by limiting infection, and thus neuroinflammation with sulfadiazine, or by application of IFN- $\gamma$-neutralizing antibodies. IFN- $\gamma$-dependent synaptic pruning might be one possible explanation for the observed neuronal changes.

\section{Methods \\ Animals}

Experiments were conducted using female, wild type (WT) C57BL/6 mice (8 weeks old; purchased from Janvier Laboratories, Cedex, France) bred under specific pathogen-free (SPF) conditions. All mice were group-housed in 12 -h day/night cycles at $22^{\circ} \mathrm{C}$ with free access to food and water. All animal experiments were approved by local authorities according to German and European legislation.

\section{Toxoplasma gondii infection}

T. gondii cysts of type II strain ME49 were harvested from the brains of female NMRI mice infected with $T$. gondii cysts $8-12$ months earlier, as described previously [34]. In short, isolated brains were mechanically homogenized in 1-ml sterile phosphate-buffered saline (PBS), and the number of cysts in the homogenate was determined using a light microscope. Mice were infected with two cysts via oral gavage (concentration adjusted to 2 cysts per $200 \mu \mathrm{l})$.

\section{Heligmosomoides polygyrus infection}

H. polygyrus was retained by serial passage in C57BL/6Rj mice as previously described [62]. Mice were infected by oral gavage with $200 \mathrm{~L} 3$ larvae in $200 \mu \mathrm{l}$ PBS.

\section{Worm fecundity and worm burden}

Adult worms were isolated from the small intestine and counted. Female worms were subsequently kept individually ( 8 per mouse) in a 96-well round-bottom plate containing RPMI, $200 \mathrm{U} / \mathrm{ml}$ penicillin, and $200 \mu \mathrm{g} / \mathrm{ml}$ streptomycin (all from PAA, Austria) at $37^{\circ} \mathrm{C}$. After 24 h, female $H$. polygyrus adults were removed from the wells and fecundity was determined by counting the eggs shed per female worm using a binocular microscope.

\section{Sulfadiazine treatment}

A solution of $400 \mathrm{mg} / \mathrm{L}$ of sulfadiazine in drinking water was prepared and then autoclaved [63]. Mice received sulfadiazine treatment in their drinking water ad libitum. Treatment began on day 10 post-infection and continued until sacrifice on day 28 post-infection.

\section{IFN- $\gamma$ neutralization}

IFN- $\gamma$ was neutralized by administration of monoclonal antibody against IFN- $\gamma$ (clone: XMG1.2, DRFZ, Berlin). Mice were treated intraperitoneally (i.p.) with $0.5 \mathrm{mg}$ anti-IFN- $\gamma$ in $200 \mu \mathrm{l}$ PBS on days 14, 17, 20, 23, and 26 post-infection [64]. Isotype IgG1 antibody (clone: 19e1, DRFZ, Berlin) was used as control. Saline injections 
were administered to non-infected and $H$. polygyrusonly-infected mice to control for the antibody treatment.

\section{Organ collection}

First, mice were deeply anesthetized by isoflurane inhalation (Baxter). Subsequently, mice were transcardially perfused with sterile ice-cold PBS. Brains were removed and stored in RPMI medium (Life Technologies) or RNAlater (Qiagen) for additional analysis. Samples were stored in RNAlater (Qiagen), were kept at $4{ }^{\circ} \mathrm{C}$ overnight, and then transferred to $-20^{\circ} \mathrm{C}$. Samples in RPMI medium were stored on ice until further experimental procedures.

\section{Cell isolation}

To isolate brain immune cells, brains were homogenized in a buffer containing $1 \mathrm{M}$ HEPES (pH 7.3) and 45\% glucose and then filtered through a 70- $\mu \mathrm{m}$ strainer. Leukocytes were separated via Percoll gradient centrifugation (GE Healthcare) as described previously [65].

\section{Flow cytometric analysis}

Single-cell suspensions were incubated with an antiFcyIII/II receptor antibody (clone 93, eBioscience) to block unspecific binding and Zombie NIR ${ }^{\mathrm{mi}}$ (Biolegend), a fixable viability dye. Thereafter, cells were stained with fluorochrome-conjugated antibodies against cell surface markers: CD45 (30-F11), CD11b (M1/70), Ly6C (HK1.4), MHCI (28-14-8), and MHCII (M5/114.15.2) all purchased from eBioscience; CD3 (17A2), CD4 (RM4-5), and $\mathrm{CD} 8 \alpha$ (53-6.7) all purchased from Biolegend; and Ly6G (1A8) purchased from BD Biosciences in FACS buffer at $4{ }^{\circ} \mathrm{C}$ for $30 \mathrm{~min}$ and then fixed in $4 \%$ paraformaldehyde (PFA, Affymetrix). Matched FMO controls were used to assess the level of background fluorescence in the respective detection channel.

Intracellular staining was performed as previously described [66]. Afterwards, cells were incubated with antiFcyIII/II receptor antibody (clone 93, eBioscience) and Zombie NIR ${ }^{\text {mix }}$ (Biolegend). Surface epitopes were then stained with CD45 (30-F11), CD11b (M1/70), Ly6C (HK1.4), Ly6G (1A8), CD3 (17A2), CD4 (RM4-5), and CD8 $\alpha$ (53-6.7). To measure cytokine expression, cells were stained with TNF (MP6-XT22), IL-12p40 (C17.8), IL-10 (JES5-16ES), purchased from eBioscience; iNOS (6, BD Biosciences); and IFN- $\gamma$ (XMG1.2, Biolegend). Matched isotype controls were used to assess the level of non-specific binding.

Flow cytometric analysis was performed on BD FACS CANTO II (BD Bioscience) and on Attune NxT Flow Cytometer (Thermo Fisher) and analyzed with FlowJo (version 10, Tree star).

\section{DNA and RNA isolation}

Samples stored in RNAlater were homogenized in BashingBeads tubes (Zymo Research, Freiburg, Germany). AllPrep DNA/RNA Mini Kit (Qiagen) was used to isolate DNA, and the peqGOLD total RNA kit (Peqlab, Erlangen, Germany) was used to isolate total RNA from the homogenate following the manufacturer's instructions, respectively.

\section{Semiquantitative PCR and RT-qPCR}

$T$. gondii burden was determined using the FastStart Essential DNA Green Master kit (Roche). The target $T$. gondii gene used was $T g B 1$, and $M m$. Asl (TIBMolbiol, Berlin, Germany) was used as a reference. The stage of parasite burden was quantified using the Power SYBR ${ }^{\circ}$ Green RNA-to-CT ${ }^{\mathrm{mo}} 1$-Step Kit (Thermo Fisher) for bradyzoite-specific Bag1 and tachyzoite-specific Sag1 using Gapdh as reference gene. All genes were purchased from TIBMolbiol, Berlin, Germany.

Relative gene expression was determined similar to previous descriptions $[67,68]$ using the TaqMan ${ }^{\circ}$ RNAto-CT ${ }^{\mathrm{Tx}}$ 1-Step Kit (Life Technologies). TaqMan ${ }^{\circ}$ Gene Expression Assays (Life Technologies) were used for mRNA amplification of $I f n-\gamma$ (Mm00801778_m1), Il10 (Mm00439616_m1), Tnf (Mm00443258_m1), Il1b (Mm00434228_m1), Il12a (Mm00434165_m1), Arg1 (Mm00475988_m1), Il6 (Mm00446190_m1), Il13 (Mm00434204_m1), Il4 (Mm0445259_m1), Nos2 (Mm00440485_m1), Trem2 (Mm04209422_m1), Bdnf (Mm04230607_s1), Syp (Mm00436850_m1), Dlg4 (Mm00492193_m1), Slc1a2 (Mm01275814_m1), Gabra1 (Mm00439046_m1), and C1qa (Mm00432142_m1). Expression of Hprt (Mm01545399_m1) was chosen as reference, and target/reference ratios were calculated with the LightCycler 96 software version 1.1 (Roche). All results were further normalized to the mean of the corresponding non-infected control group.

\section{Statistical analysis}

Data sets were statistically analyzed using SPSS 22.0 (IBM, Armonk, NY). To account for the factorial nature of our experiments and the multiple measures of outcome, we computed ANOVA models with infection status and or treatment as between-subjects factors and different outcome measures (e.g., cell counts, gene expression) as within-subject factors or dependent variables. Whenever we could assume a positive correlation between outcome measures, ANOVAs for repeated measures were employed, and otherwise, MANOVAs were used. When data from different series of experiments or different PCR plates were analyzed in the same statistical model, appropriate covariates were included. Whenever a within-subjects factor had more than two levels, degrees of 
freedom were corrected for non-sphericity using the Greenhouse-Geisser correction. ANOVAs with significant effects of interest were followed by planned $t$ test comparisons to assess directionality of the observed effects. Owing to the small sample sizes, unequal variances were assumed in all $t$ tests. The significance level was set to $p<.05$ for all statistical comparisons, and two-tailed $p$ values are reported for all $t$ tests unless otherwise stated.

Diagrams were generated using GraphPad Prism 6.0 (GraphPad Software). Data are presented as mean \pm SEM.

\section{Results}

H. polygyrus co-infection amplifies the Th1 response to $T$. gondii in the brain

On day 14 post $T$. gondii infection, after the parasites had crossed the blood-brain barrier (BBB) and provoked a CNS immune response, mice were co-infected with $H$. polygyrus. Immune cell collection took place on day 28 , thus 14 days post $H$. polygyrus infection and during the acute phase of the helminth infection (Fig. 1a). To determine whether an acute intestinal helminth infection affects $T$. gondii-dependent neuroinflammation, we used qRT-PCR to examine changes in cytokine gene expression levels in whole-brain homogenates (Fig. 1b-k). Gene expression analysis of the pro-inflammatory cytokines IFN- $\gamma$, TNF, and IL-12, which have previously been implicated in the immune response to T. gondii $[69,70]$, showed significant effects of both $T$. gondii $\left(F_{1,14}=\right.$ $311.85, p<0.001$; three-way ANOVA for repeated measures with cytokine as within-subjects factor and $T$. gondii and $H$. polygyrus as between-subjects factors) and $H$. polygyrus $\left(F_{1,14}=11.55, p=0.004\right)$ infection, as well as an interaction of the two pathogens $\left(F_{1,14}=10.77\right.$, $p=0.005)$. We further observed interactions of both pathogens and their combination with cytokine, reflecting differential effects on IFN- $\gamma$, TNF, and IL-12 (all $F>$ 8.40 , all $p<0.010$ ). Specifically, co-infected mice compared to mice infected with $T$. gondii only showed significantly higher expression of IFN- $\gamma$ (post hoc two-

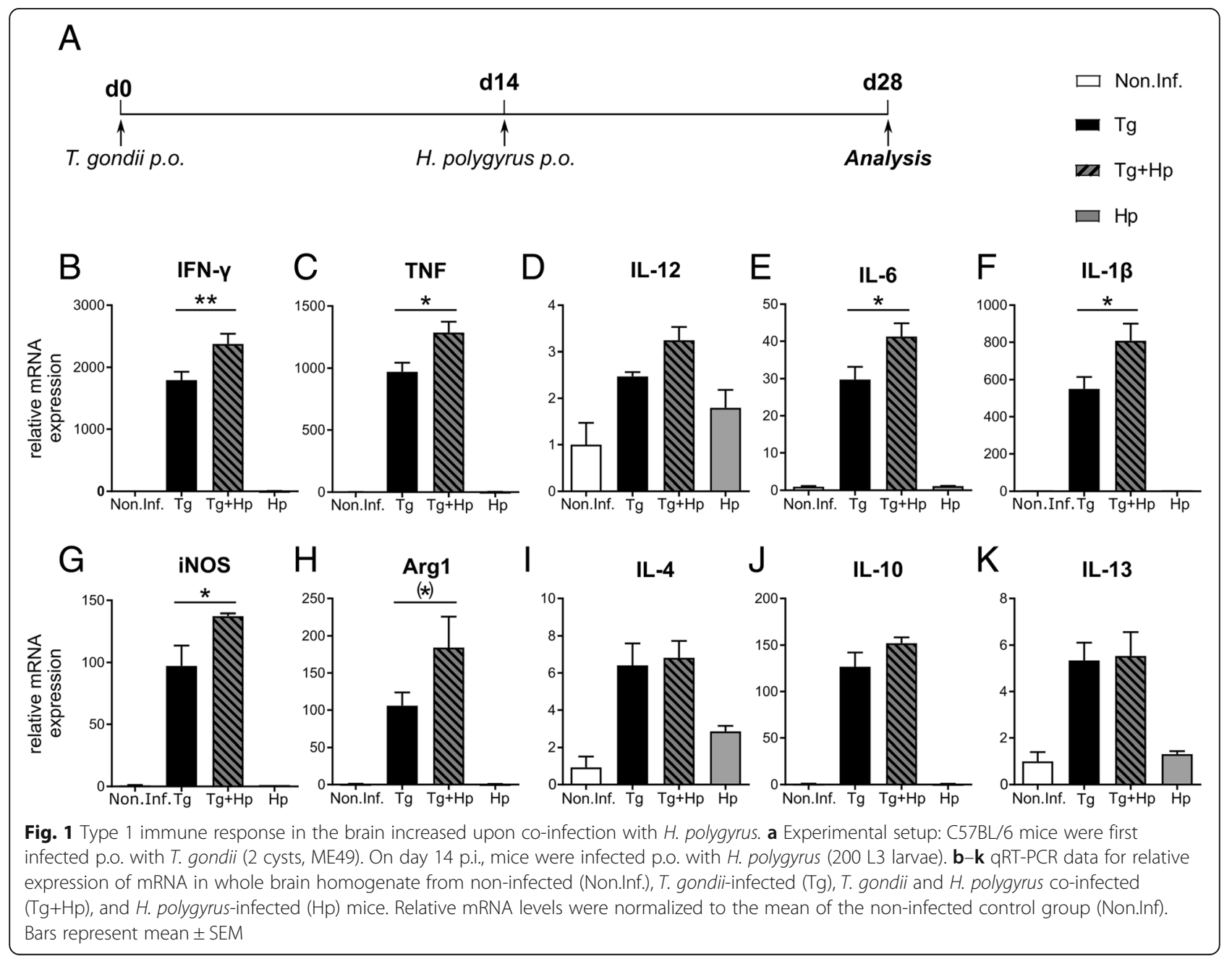


sample $t$ test: $\left.t_{7.4}=3.51, p=0.009\right)$ and TNF $\left(t_{7.7}=2.74\right.$, $p=0.026)$, while the difference in IL-12 expression was not significant $(p=0.591)$ (Fig. $1 \mathrm{~b}-\mathrm{d}) . H$. polygyrus-infected mice compared to uninfected mice, on the other hand, exhibited significantly increased expression of TNF $\left(t_{6.9}=2.82, p=0.026\right)$, but not IFN- $\gamma$ or IL-12 (all $p>0.238)$.

When testing for expression changes of IL-4, IL-10, and IL-13 as mediators of the Th2 or anti-inflammatory responses, we found a significant main effect of $T$. gondii infection $\left(F_{1,12}=206.22, p<0.001\right.$; threeway ANOVA for repeated measures with cytokine as within-subjects factor and $T$. gondii and $H$. polygyrus as between-subjects factors) as well as a cytokine by $T$. gondii interaction $\left(F_{1.0,12.2}=147.70, p<0.001\right)$, but no effects related to $H$. polygyrus infection alone or in interaction with $T$. gondii interaction (all $p>0.187$ ) (Fig. 1e-g). Together with the additive effects of $T$. gondii and $H$. polygyrus on IFN- $\gamma$ and TNF expression, these results suggest that a co-infection with the enteric nematode $H$. polygyrus during the acute phase of the helminth infection shifts the balance of Th1/ Th2 responses towards an increased Th1-type cytokine response.

In an exploratory analysis, we further assessed the effects of $T$. gondii and $H$. polygyrus infection on several additional markers previously implicated in the immune responses to $T$. gondii infection (Arg1, IL-6, IL-1 $\beta$, and iNOS; Fig. 1h-k; see [71]), revealing effects of both T. gondii (three-way ANOVA for repeated measures with gene as within-subjects factor and $T$. gondii and $H$. polygyrus infection as betweensubjects factors: $\left.F_{1}, 12=145.05, p<0.001\right)$ and $H$. polygyrus $\left(F_{1,12}=7.10, p=0.021\right)$ as well as an interaction $\left(F_{1}, 12=7.13, p=0.020\right)$. The observed interaction was driven by increased expression of IL-1 $\beta$ $\left(t_{5.9}=2.29, p=0.033\right.$, one-tailed $)$, IL-6 $\left(t_{6.8}=2.33, p=\right.$ 0.027 , one-tailed), and iNOS $\left(t_{4.1}=2.41, p=0.036\right.$, one-tailed) in co-infected animals compared to animals infected with $T$. gondii only, whereas no single marker showed a significant difference between uninfected mice and mice infected with $H$. polygyrus only (all one-tailed $p>0.155$ ).

Given the more pronounced clearance of $T$. gondii and lack of a Th2 response in co-infected mice, we investigated the immune response to $H$. polygyrus. To this end, we examined the gene expression of Th2 cytokines IL-4 and IL-13 (characteristic of $H$. polygyrus infection) in the spleens of mice (Additional file 1: Figure S1A-B). There was a pronounced interactive effect of the parasites on cytokine infection $\left(F_{1,14}=308.30, p<0.001\right.$; three-way ANOVA for repeated measures with cytokine as withinsubjects factor and $T$. gondii and $H$. polygyrus as between-subjects factors), reflecting the significantly higher expression of both IL-4 and IL-13 in mice infected with $H$. polygyrus only compared to all other groups (all $t>$ 11.93, all $p<0.001)$. Furthermore, both mice infected with $T$. gondii alone and co-infected animals showed lower splenic expression of IL-4 and IL-13 compared to uninfected mice (all $t>8.76$, all $p<0.002$ ). From these data, we concluded that mice were capable of manifesting an immune response to $H$. polygyrus, but that their immune response was shifted from a Th2- to Th1-type response when $T$. gondii infection was present.

\section{Altered immune response results in reduced parasite burden in the brain}

To investigate if the immune response reflected by the increase in $T$. gondii-related cytokines influenced the overall parasite burden, we measured DNA levels of $T$. gondii-specific gene $T g B 1$ in the brains of infected animals. TgB1 DNA levels were significantly decreased in co-infected animals compared to mice infected with $T$. gondii only $\left(t_{7.9}=3.24, p=0.012\right.$; Fig. 2a). Expression analysis of stage-specific genes for tachyzoites (Tgsag1) and bradyzoites (Tgbag1) further showed that the decreased parasite burden was largely attributable to fast-replicating, highly virulent tachyzoites $\left(t_{7.5}=2.86, p=0.022\right.$; Fig. $\left.2 \mathrm{~b}\right)$, while the burden of less virulent, slow-replicating bradyzoites did not change significantly $\left(t_{7.4}=0.83, p=0.433\right.$; Fig. 2c). These results suggest that the increased Th1 response in co-infected mice actually increased the effectiveness of $T$. gondii elimination.

In accordance with these results, we next investigated how the co-infection affected the ability to control the $H$. polygyrus infection. To this end, we examined worm burden and worm fecundity from co-infected compared to $H$. polygyrus-only infected animals (Fig. 2d-e). We observed no significant change in worm burden $\left(F_{1,20}=0.02, \quad p=0.889\right.$; ANCOVA with infection status as fixed factor and experiment as covariate). Regarding worm fecundity in co-infected animals compared to mice infected with $H$. polygyrus alone, we observed nominally lower egg counts in co-infected animals, although this did not reach significance when testing conservatively (ANCOVA with average egg count per mouse as dependent variable, infection status as fixed factor, and standard deviation of egg count and number of worms counted as covariates: $F_{1,6}=2.46$, $p=0.168$ ). When directly comparing the number of eggs per worm as a function of infection status, the average number of eggs was indeed significantly higher in co-infected mice $\left(t_{60.3}=3.28, p=0.002\right)$, suggesting a (minor) detrimental effect of $T$. gondii infection on helminth elimination. 


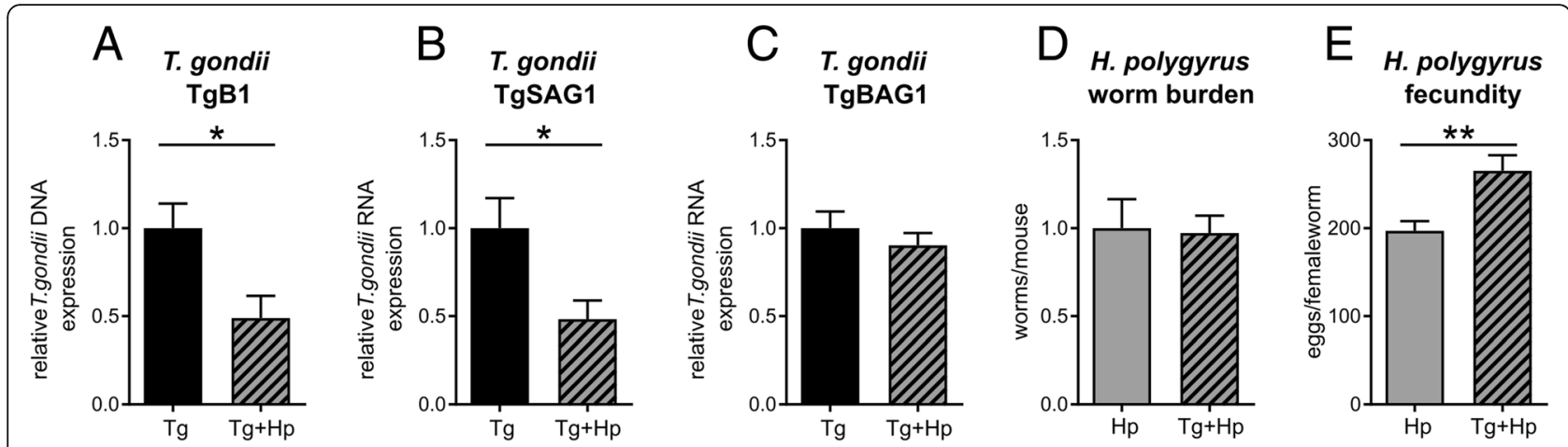

Fig. 2 Parasite burden decreases and worm fecundity increases upon H. polygyrus co-infection. a-c $T$. gondii parasite burden in the brains of $T$. gondii infected $(\mathrm{Tg})$ and $\mathrm{T}$. gondii and $\mathrm{H}$. polygyrus co-infected $(\mathrm{Tg}+\mathrm{Hp})$ mice. qPCR and qRT-PCR data of relative expression of T. gondii genes TgB1 (a), Sag1 (b), and Bag1 (c), normalized to the T. gondii infected (Tg) group. d H. polygyrus worm burden. e Fecundity of female worms. Bars represent mean \pm SEM

Acute $H$. polygyrus co-infection amplifies Th1 response of brain recruited and resident immune cells

To characterize the cellular composition and uncover the origin of the cytokines responsible for the inflammatory response to the parasites, we analyzed the immune cell subsets in the brain during the infection. The control and subsequent resolution of neuroinflammation requires resident immune cell activation and the persistent recruitment of peripheral immune cells. Accordingly, we characterized resident microglia and recruited immune cell populations. Using hematopoietic cell marker CD45 and myeloid marker $\mathrm{CD} 11 \mathrm{~b}$, we distinguished the resident and recruited immune cell populations via fluorescence-assisted cell sorting (FACS), as described previously [23, 72]. In both non-infected mice and mice infected with $H$. polygyrus only, the prevailing immune cell population was the $\mathrm{CD} 45^{\mathrm{lo}} \mathrm{CD} 11 \mathrm{~b}^{+}$ resident microglia, and the infiltration by peripheral $\mathrm{CD} 45^{+}$ leukocytes was absent (Fig. 3a). In the brains of T. gondiiinfected and nematode co-infected mice, we observed an infiltration of peripheral $\mathrm{CD} 45^{\mathrm{hi}} \mathrm{CD} 11 \mathrm{~b}^{-}$lymphocytes and $\mathrm{CD} 45^{\text {hi }} \mathrm{CD} 11 \mathrm{~b}^{+}$myeloid cells along with a population of activated microglia characterized by an increased expression of CD45 (Fig. 3b).

To further characterize the immune cell recruitment to the brain, we next assessed the abundance of Ly6C monocyte subpopulations as a function of infection status. Recruitment of Ly6C-positive cell populations $\left(\right.$ Ly6C $C^{\text {hi }}$ Ly6C ${ }^{\text {int }}$, and Ly6C $^{\text {lo }}$ ) was affected by both $T$. gondii (MANOVA with cell populations as dependent variables and pathogens as fixed factor: $F_{3,11}=162.9$, Wilks' $\Lambda=0.022, p<0.001)$ and, to a lesser extent, $H$. polygyrus $\left(F_{3,11}=3.82\right.$, Wilks' $\left.\Lambda=0.488, p=0.042\right)$, and there was a significant interaction between the two pathogens $\left(F_{3,11}=3.88\right.$, Wilks' $\left.\Lambda=0.486, p=0.041\right)$. While $T$. gondii infection was associated with recruitment of all three cell types (all $F>70.99$, all $p<0.001$ ), $H$. polygyrus and its interaction with $T$. gondii selectively affected the recruitment of Ly6C ${ }^{\text {hi }}$ monocytes (all $F>10.28$, all $p<$ 0.007 ), but not Ly6C $C^{\text {int }}$ or Ly6C $C^{\text {lo }}$ cells (all $F>0.95$, all $p>0.348)$. In direct comparisons, we found a significantly higher proportion of Ly6C $\mathrm{C}^{\text {hi }}$ inflammatory monocytes in the brains of co-infected mice compared to animals solely infected with $T$. gondii $\left(t_{5.9}=3.35, p=\right.$ 0.016; Fig. 3c), whereas no difference was detectable for Ly6C ${ }^{\text {int }}$ or Ly $6 C^{\text {lo }}$ mononuclear cells (all $t<1.07$, all $p>$ 0.320; Fig. 3c).

We next characterized the activation status of microglia and recruited mononuclear cells by assessing their expression status for the class II major histocompatibility complex (MHC II). Because of the very low MHC II expression by microglia in uninfected mice and mice infected with $H$. polygyrus only (Fig. $3 \mathrm{~d}$ ), we restricted statistical analysis to co-infected mice and mice solely infected with T. gondii. When testing for MHC II expression across cell populations (microglia, Ly6C ${ }^{\text {hi }}$, Ly $6 C^{\text {int }}$, and $L y 6 C^{\text {lo }}$ ), we found a significant increase in MHC II expression in Ly6C ${ }^{\text {hi }}$ mononuclear cells (MANOVA with infection status as fixed factor: $F_{4,3}=9.85$, Wilks' $\Lambda=0.071, p=0.045$; post hoc $t$ test: $t_{3.6}=5.82$, $p=0.006)$ and a trend-wise increase of MHC II expression in microglia $\left(t_{5.5}=2.12, p=0.041\right.$, one-tailed; see Fig. $3 d$, e) of the co-infected mice, whereas no robust differences were evident for Ly6C ${ }^{\text {int }}$ or Ly6 $\mathrm{C}^{\text {lo }}$ cells (all $t<1.78$, all $p>0.065$, one-tailed).

Given the importance of the Th1 response in the control of a $T$. gondii infection and the observed reduction of brain parasite burden (see above), we next compared the expression of Th1 response-related genes (IL-12, TNF, iNOS, and IL-10) in recruited mononuclear cells of co-infected animals versus animals infected with $T$. gondii only. When comparing the percentages of cytokine-producing cells (Fig. 3f, h, j, and l) across cell types (microglia, Ly $6 C^{\text {hi }}$, Ly $6 C^{\text {int }}$, and $L y 6 C^{\text {lo }}$ ), we found a significant modulation of cytokine levels as a function of cell type, 


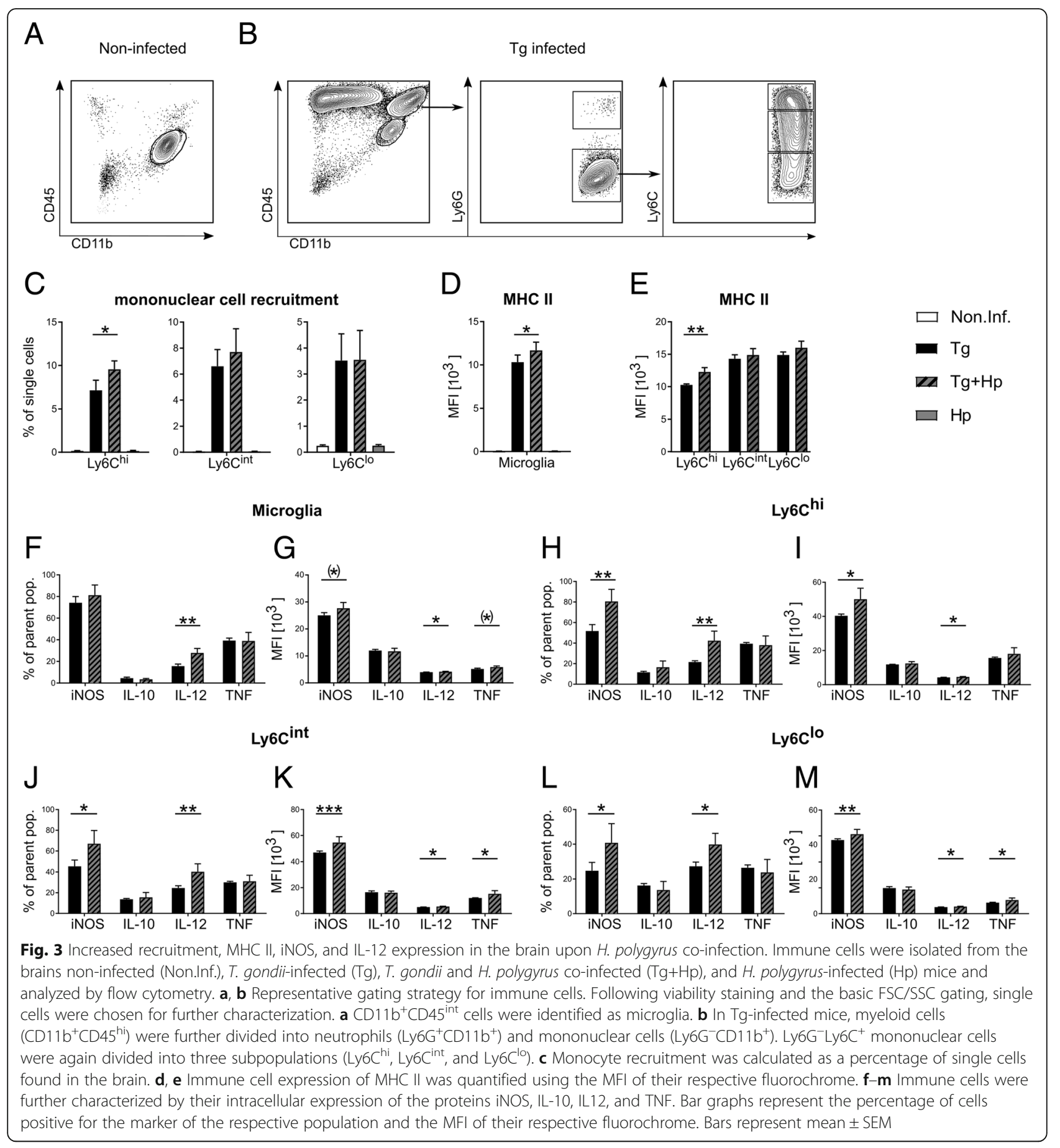

infection status, and gene as well as a significant interaction of cell type and infection status and a three-way interaction cell type by gene by infection status (three-way ANOVA for repeated measures with gene and cell type as within-subjects factors and infection status as betweensubject factor: all $F>12.70$, all $p<0.009$; GreenhouseGeisser correction applied). These effects could be attributed to co-infected animals showing higher proportions of IL-12-positive cells across all cell types (post hoc two-sample $t$ tests: all $t>3.29$, all $p<0.013$ ) and slightly higher proportions of iNOS-expressing Ly6C cells (all $t>$ 2.29 , all $p<0.058$, one-tailed), but not microglia $\left(t_{3.9}=\right.$ $1.16, p=0.182$, one-tailed). When testing for mean fluorescence intensity (Fig. 3g, i, k, and $\mathrm{m}$ ), a similar pattern emerged with main effects of cell type, gene, and infection status as well as significant interactions of cell type and infection status, cell type and gene, and gene and infection status (all $F>5.37$, all $p<0.039$; Greenhouse-Geisser 
correction applied), plus a trend-wise three-way interaction (all $F>3.17, p=0.063$; Greenhouse-Geisser correction applied). These effects could be attributed to increased expression of IL-12 in all cell types of coinfected animals compared to animals infected with $T$. gondii only (post hoc two-sample $t$ tests: all $t>2.46$, all $p<0.026$, one-tailed) and to all three mononuclear cell subsets $\left(\right.$ Ly6C $C^{\text {hi }}$, Ly6C ${ }^{\text {int }}$, and $\mathrm{Ly}_{6 \mathrm{C}} \mathrm{C}^{\mathrm{lo}}$ ) showing a higher expression of iNOS in co-infected animals (all $t>2.38$, all $p<0.027$, one-tailed) when compared to only $T$. gondiionly infected mice. Additionally, co-infected animals showed higher expression levels of TNF in $\mathrm{Ly}_{6} \mathrm{C}^{\text {int }}$ and Ly6 $\mathrm{C}^{\mathrm{lo}}$ monocytes (all $t>2.61$, all $p<0.049$ ) and, as a trend, in microglia $\left(t_{4.9}=2.01, p=0.047\right.$, one-tailed). IL-10 levels were not affected by $H$. polygyrus in any cell population (all $t<1.13$, all $p>0.157$, one-tailed).

The major role of IL-12 in chronic T. gondii infection is sustaining IFN- $\gamma$ production [69]. Thus, we examined how $\mathrm{T}$ cell subsets (the primary IFN- $\gamma$ producers in chronic infection) are affected by co-infection. $\mathrm{CD} 45^{+} \mathrm{CD} 11 \mathrm{~b}^{-}$lymphocytes were further gated for T cells based on CD3 expression and subsequently separated into $\mathrm{CD} 4^{+}$and $\mathrm{CD} 8 \alpha^{+}$populations (Fig. 4a). The recruitment of $\mathrm{CD}^{+}$or $\mathrm{CD} 8 \alpha^{+} \mathrm{T}$ cells to the brain was unchanged in $T$. gondii-infected and co-infected mice (MANOVA with cell type as dependent variable and infection status as fixed factor: $F_{2,7}=2.65$, Wilks' $\Lambda=0.569, p=0.139$; Fig. $4 \mathrm{c}$ ). There was, however, a pronounced increase in the percentage of both $\mathrm{CD}^{+} \mathrm{CD} 4^{+}$and $\mathrm{CD} 3^{+} \mathrm{CD} 8 \alpha^{+} \mathrm{T}$ cells that were positive for IFN- $\gamma$ and TNF in co-infected compared to $T$. gondii-infected animals (main effect of infection status: $F_{1,8}=43.52, p<0.001$; three-way ANOVA for repeated measures with cell type and cytokine as withinsubjects factors and infection status as between-subjects factor; post hoc two-sample $t$ tests: all $t>4.13$, all $p<$ 0.007; Fig. $4 \mathrm{~d}$ and e). When comparing mean fluorescence intensities, a three-way ANOVA for repeated measures with cell type and cytokine as within-subjects factors and infection status as between-subjects factor revealed a highly significant three-way interaction of cell type, cytokine, and infection status $\left(F_{1,8}=15.54, p=0.004\right)$, reflecting an increased expression of IFN- $\gamma$ in $\mathrm{CD}^{+}$ lymphocytes (post hoc two-sample $t$ test: $t_{4.3}=2.31, p=$ 0.036, one-tailed), while no further significant differences were observed (all $t<0.916$, all $p>0.197$, one-tailed). Taken together, these results indicate that $T$. gondii co-infection with an acute $H$. polygyrus infection strongly increases the proportion of IFN- $\gamma$-producing $\mathrm{T}$ cells in $T$. gondii-infected mice.

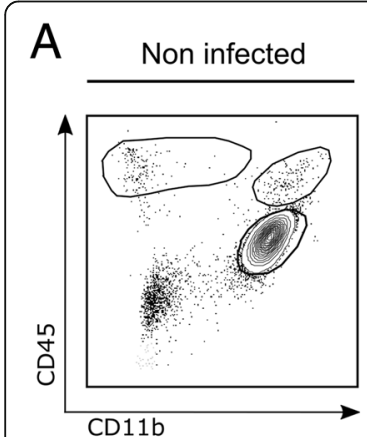

C

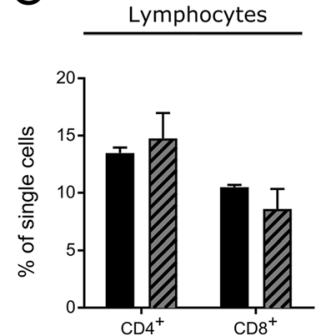

B

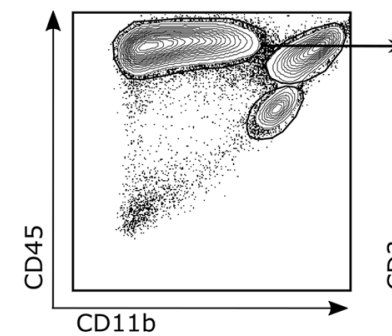

D

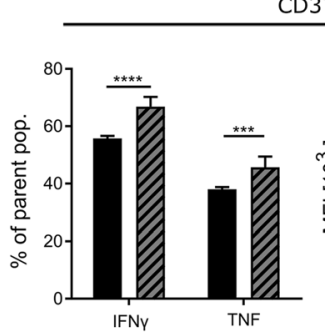

Tg infected

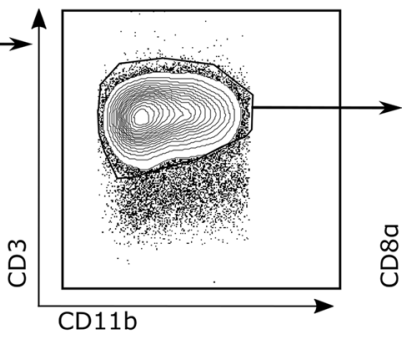

E

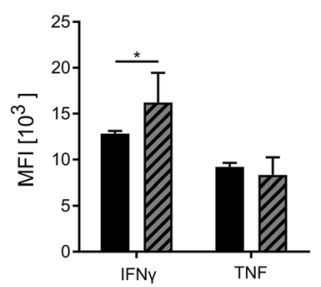

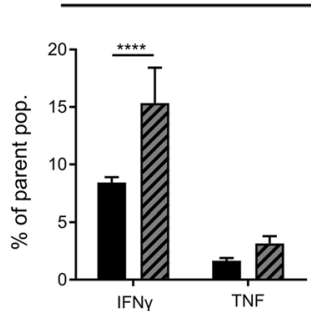

$\mathrm{CD}^{+} \mathrm{CD} 8 \mathrm{a}^{+}$

Fig. 4 Increased type 1 response in T cells in the brain upon co-infection with $H$. polygyrus. Immune cells were isolated from the brains of $T$. gondii-infected and T. gondii and H. polygyrus co-infected mice and analyzed by flow cytometry. a, b Representative gating strategy for lymphocyte populations. Following a viability staining and FSC/SSC gating, single cells were chosen for further characterization. a In both noninfected and $\mathrm{H}$. polygyrus-infected mice, there was an absence of recruited CD45 leukocytes. $\mathbf{b}$ In both Tg-infected and Tg and Hp co-infected mice, CD11 b ${ }^{-}$CD45 hi cells were identified as lymphocytes and then further gated for CD3 expression. CD3 ${ }^{+}$lymphocytes were additionally gated for $\mathrm{CD}^{+}$and $\mathrm{CD} \mathrm{a}^{+} \mathrm{T}$ cells. c Lymphocyte recruitment was calculated as a percentage of single cells found in the brain. $\mathbf{d}$, e Intracellular expression of proteins in T cells was characterized by the percentage of cells positive for IFN- $\gamma$ or TNF and the MFI of the positive cells of each respective marker. Bars represent mean \pm SEM 
Acute $H$. polygyrus co-infection enhances the $T$. gondii infection-induced decrease of synaptic gene expression Guided by previous observation that $T$. gondii-induced neuroinflammation affects the synaptic protein composition [35], and particularly glutamatergic neurotransmission [34, 73], we next set out to investigate if the enhanced Th1 response influenced the gene expression of synaptic markers in co-infected mice. We focused our analyses on the pre-synaptic vesicle protein synaptophysin (Syp), the post-synaptic scaffolding protein PSD-95 encoded by the Dlg4 gene, the glutamate transporter EAAT2 encoded by the Slc1a2 gene, and the $\alpha 1$ subunit of the GABA-A receptor $\left(\mathrm{GABA}_{\mathrm{A}} \alpha 1\right)$ encoded by the Gabra1 gene as well as the brain-derived neurotrophic factor (BDNF), given its key role in synaptic plasticity and learning [74, 75]. Expression levels were strongly affected by $T$. gondii (three-way ANOVA for repeated measures with expressed gene as within-subjects factor and $T$. gondii and $H$. polygyrus as between-subjects factors; main effect: $F_{1,13}=193.87, p<0.001$; interaction with gene: $F_{1.2}, \quad 15.1=166.34, p<0.001$ ) and to a lesser, but significant extent, by $H$. polygyrus (main effect: $F_{1,13}=6.68, p=0.023$; interaction with gene: $F_{1.2}, 15.1=6.26, p=0.038$ ), whereas no formal interactions between the pathogens were observed (all $F<2.00$, all $p>0.208$ ). All genes investigated were markedly reduced in mice infected with T. gondii compared to uninfected mice (post hoc two-sample $t$ tests: all $t>4.98$, all $p<0.002$; Fig. 5a-e), in line with our previous proteomics study [35]. Co-infection aggravated this pattern, as expression of EAAT2 and $\mathrm{GABA}_{\mathrm{A}} \alpha 1$ was significantly lower in co-infected mice compared to mice infected with $T$. gondii only (EAAT2: $t_{4.3}=2.90, p=$ $0.041 ; \mathrm{GABA}_{\mathrm{A}} \alpha 1: t_{5.1}=2.56, p=0.050$; Fig. $\left.5 \mathrm{~d}, \mathrm{e}\right)$. When compared to uninfected mice, mice infected with $H$. polygyrus alone showed reduced expression levels of $\mathrm{GABA}_{\mathrm{A}} \alpha 1\left(t_{4.4}=3.75, p=0.017\right)$ and BDNF $\left(t_{4.3}=4.32, p=0.011\right.$; Fig. 5c, e). Collectively, these data suggest that an acute nematode co-infection amplifies the decrease of synaptic protein gene expression induced by $T$. gondii, possibly by exerting an additive effect via systemic inflammatory activity.

\section{Sulfadiazine reduces inflammation and attenuates loss of synaptic gene expression}

We next treated mice with sulfadiazine, which targets the fast-replicating tachyzoite stages of infection and as a consequence markedly reduces the strength of the Th1 inflammatory response [76]. To assess if sulfadiazine treatment could indeed reduce $T$. gondii-induced neuroinflammation, we investigated how pro-inflammatory cytokine gene expression was affected. When comparing expression levels of inflammation-related genes in $T$. gondii-infected and co-infected mice treated with sulfadiazine to those in untreated animals, we observed significant effects of $H$. polygyrus infection (main effect: $F_{1}, 1_{13}=16.94, \quad p=0.001$; three-way ANOVA for repeated measures with gene as withinsubjects factor and $H$. polygyrus infection and sulfadiazine treatment as between-subjects factors) and treatment (main effect: $F_{1,13}=82.73, p<0.001$ ), but only a trend-wise interaction. Animals infected with $T$. gondii alone showed a treatment-related reduction of gene expression for IFN- $\gamma$, iNOS, IL-1 $\beta$, IL-10, and Arg1 (post hoc two-sample $t$ tests: all $t>4.61$, all $p<0.008$; Fig. 6a, $c-f)$. When comparing untreated co-infected mice to co-infected mice treated with sulfadiazine, the same genes showed significantly reduced expression, and there was additionally a significant reduction of IL-12 gene expression (all $t>3.22$, all $p<0.036$; Fig. 6a-f).

To assess whether a reduced neuroinflammatory response in sulfadiazine-treated animals would be associated with an attenuation of the synaptic alterations, we next examined the effects of sulfadiazine treatment on the reduction of synaptic marker gene expression. As expected, we observed effects of $T$. gondii infection (four-way ANOVA for repeated measures with gene as within-subjects factor and $T$.
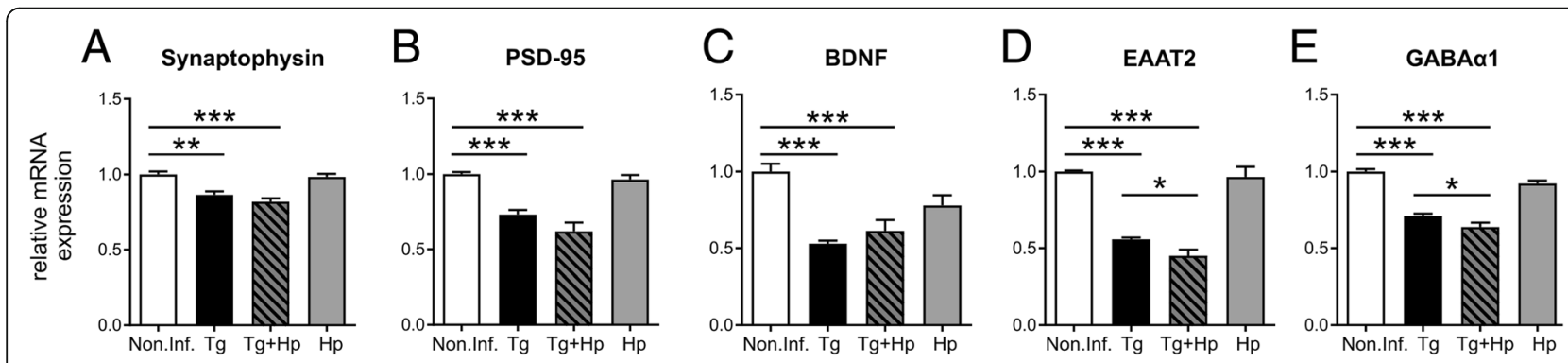

Fig. 5 Impairment of synaptic gene expression in the brain upon co-infection with H. polygyrus. a-e qRT-PCR data for relative expression of mRNA in whole brain homogenate from non-infected (Non.Inf.), T. gondii-infected (Tg), T. gondii and H. polygyrus co-infected (Tg+Hp), and H. polygyrus-infected (Hp) mice. Relative mRNA levels were normalized to the mean of the non-infected control group (Non.Inf). Bars represent mean \pm SEM 

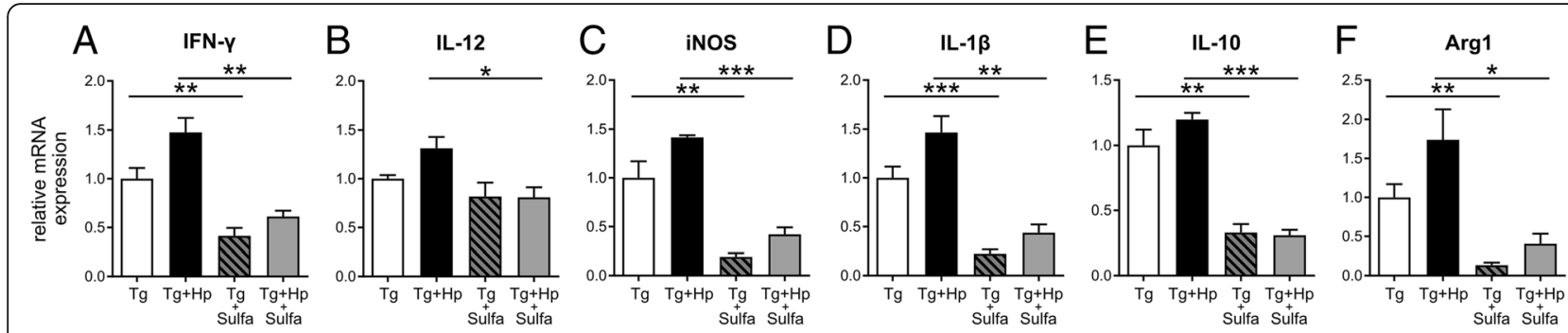

Fig. 6 Sulfadiazine treatment reduces the gene expression of pro-inflammatory mediators upon T. gondii infection. RNA was isolated from whole brain homogenate of $T$. gondii-infected and co-infected mice with or without sulfadiazine treatment. (a-f) qRT-PCR data for relative expression of mRNA in whole brain homogenate from $T$. gondii-infected $(\mathrm{Tg}), T$. gondii and $H$. polygyrus co-infected $(\mathrm{Tg}+\mathrm{Hp})$, $T$. gondii-infected and sulfadiazinetreated ( $\mathrm{Tg}+\mathrm{Sulfa}$ ), and T. gondii and $\mathrm{H}$. polygyrus co-infected and sulfadiazine treated ( $\mathrm{TgHp}+\mathrm{Sulfa}$ ) mice. Relative mRNA levels were normalized to the mean of the $T$. gondii-infected group. Bars represent mean \pm SEM

gondii, $H$. polygyrus, and sulfadiazine treatment as between-subjects; main effect: $F_{1,23}=55.09, p<0.001$; interaction with gene: $\left.F_{1.4}, 33.0=30.54, p<0.001\right)$ and co-infection (interaction $T$. gondii $* H$. polygyrus: $F_{1}$, ${ }_{23}=6.14, p=0.021$; interaction with gene: $F_{1.4,33.0}=$ 3.97, $p=0.041$ ). More importantly, there was a significant interaction between $T$. gondii infection and sulfadiazine treatment $\left(F_{1,23}=11.70, p=0.002\right.$; interaction with gene: $\left.F_{1.4}, 33.0=6.68, p=0.008\right)$ and a trend-wise three-way interaction $(T$. gondii $* H$. polygyrus * treatment: $\left.F_{1,23}=3.53, p=0.073\right)$. Compared to untreated animals, $T$. gondii-infected mice treated with sulfadiazine to infected showed a significantly higher expression of EAAT2 (post hoc two-sample $t$ test: $t_{6.0}=$
8.82, $p<0.001)$ and $\operatorname{BDNF}\left(t_{3.1}=4.91, p=0.015\right)$. In co-infected mice, the attenuation of synaptic gene expression loss by sulfadiazine treatment was even more pronounced with all genes examined except PSD-95 showing significantly higher expression levels in treated animals (all $t>3.26$, all $p<0.035$ ). On the other hand, sulfadiazine treatment did not significantly affect the synaptic gene expression in mice infected with $H$. polygyrus only or in non-infected mice (all $t<1.47$, all $p>0.192$ ), thus excluding unspecific effects of sulfadiazine on gene expression of synaptic proteins (Fig. 7a-e). Taken together, these results suggest that sulfadiazine treatment successfully reduced the strength of the $T$. gondii infection-

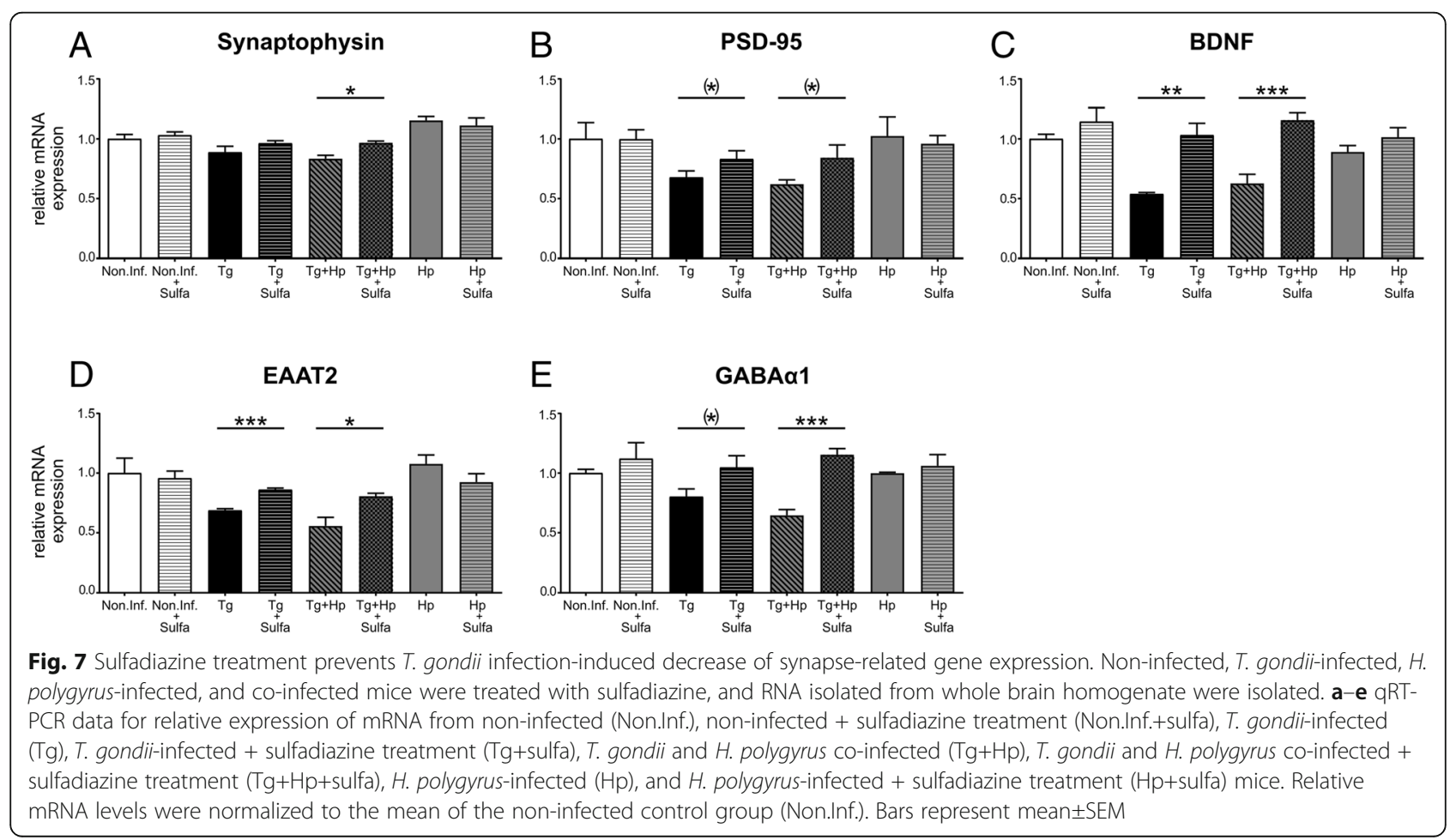


induced neuroinflammation, thereby attenuating changes to synaptic gene expression.

\section{IFN- $\gamma$ neutralization inhibits antiparasitic response and partly recovers synaptic gene expression}

Considering the key role of IFN- $\gamma$ in the antiparasitic response and its previously described effects on GABAergic signaling [6], along with the reduction in EAAT2 and $\mathrm{GABA}_{\mathrm{A}} \alpha 1$ mRNA expression observed here, we hypothesized that neutralizing IFN- $\gamma$ would rescue the loss of synaptic gene expression described above. When co-infected mice were treated with IFN$\gamma$-neutralizing antibodies, gene expression of synaptic proteins was significantly changed compared to untreated co-infected animals (main effect of $\alpha \mathrm{IFN}-\gamma$ treatment: $F_{1}, 8=13.60, p=0.006$; interaction treatment by gene: $F_{1.2}, 9.4=12.10, p=0.005$; two-way ANOVA for repeated measures with gene as withinsubjects factor and treatment as between-subjects factor). Specifically, IFN- $\gamma$-neutralized animals exhibited significant gene expression level changes for Syp, PSD-95, and EAAT2 (post hoc two-sample $t$ tests: all $t>2.47$, all $p<0.040$ ) as well as a trend-wise rescue of $\mathrm{GABA}_{\mathrm{A}} \alpha 1$ expression $\left(t_{4.2}=2.70, p=0.026\right.$, one-tailed) (Fig. 8a, b, d, e), whereas BDNF showed no difference in gene transcription as a function of $\alpha \mathrm{IFN}-\gamma$ treatment (Fig. 8c).

We next examined how $\alpha I F N-\gamma$ treatment affected the parasite burden of the co-infected mice. We found the specific antigens of both tachyzoites and bradyzoites to be significantly increased in IFN- $\gamma$-neutralized mice when compared to untreated co-infected animals (Tgbag1: $t_{5.0}=4.51, p=0.006 ;$ Tgsag1: $t_{5.4}=$ 5.37, $p=0.002$, Fig. 8j, k). As a reduced parasite load could thus not explain the rescue of synaptic gene expression, we next aimed to elucidate if neurotoxic or phagocytic immune cell activity might be involved in the altered synaptic gene expression. To assess potentially increased cytotoxic activity, we examined expression of iNOS in $\alpha$ IFN- $\gamma$-treated compared to

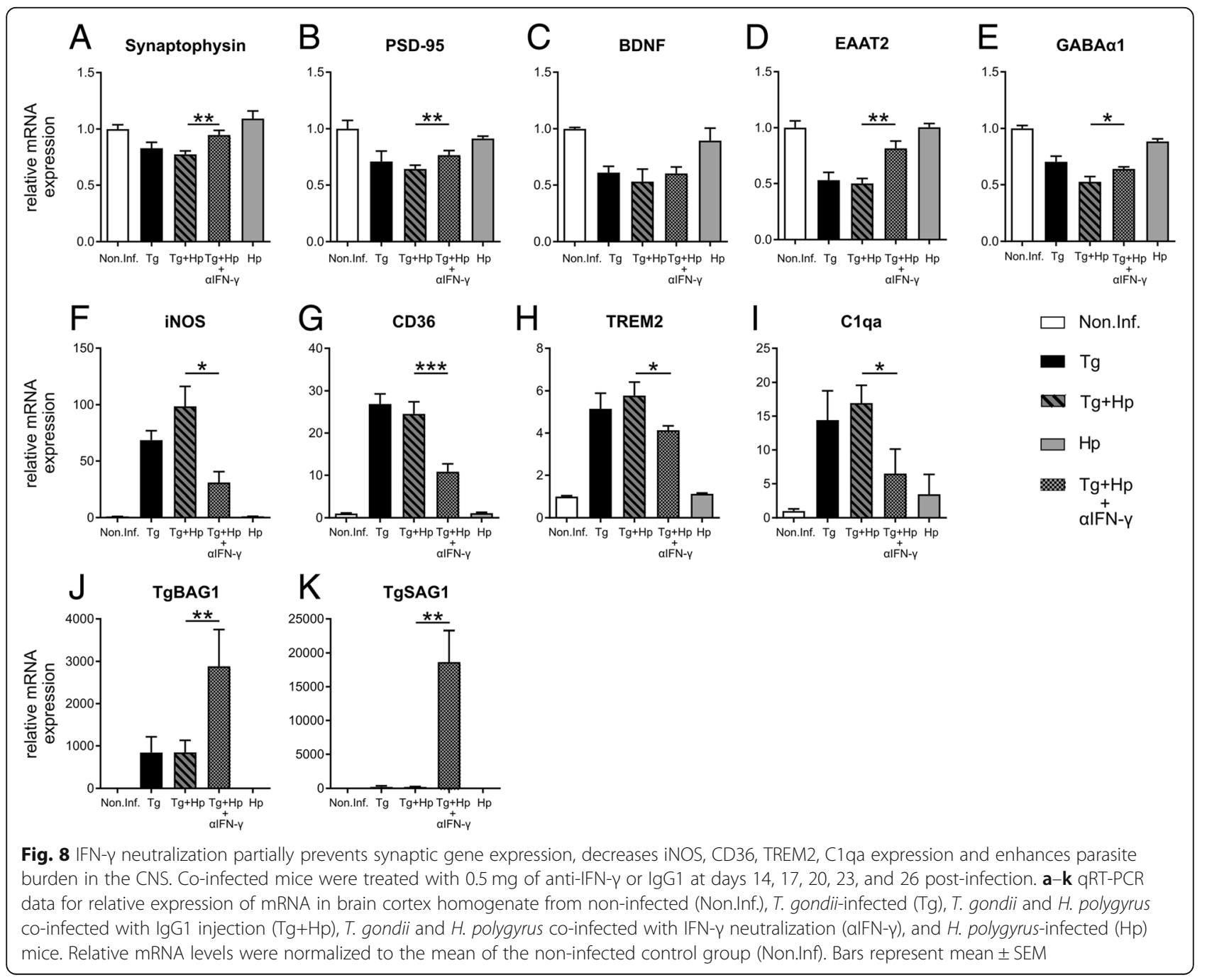


untreated animals. Indeed, iNOS expression decreased as a function of IFN- $\gamma$ antagonization $\left(t_{4.7}=3.34, p=\right.$ 0.022 ). We next aimed to test whether phagocytic activity might be affected by $\alpha \mathrm{IFN}-\gamma$ treatment and thus examined gene expression of CD36 and TREM2 (markers involved in phagocytosis, parasite killing, scavenging, and synaptic pruning) in treated compared to untreated animals. Both markers were significantly reduced in $\alpha I F N-\gamma$-treated compared to untreated co-infected mice (two-way ANOVA for repeated measures with gene as within-subjects factor and $\alpha I F N-\gamma$ treatment as between-subjects factor: main effect: $F_{1,8}=18.04, p=0.002$; interaction: $F_{1,8}=$ 6.43, $p=0.035$; post hoc two-sample $t$ tests: CD36: $t_{7.1}=5.08, \quad p=0.001 ; \quad$ TREM2: $\left.t_{4.1}=3.42, \quad p=0.025\right)$ (Fig. $8 \mathrm{f}-\mathrm{i}$ ), suggesting a role for phagocytosis and synaptic pruning in the reduced synaptic gene expression. As phagocytosis is typically promoted by activation of the complement system, we further tested for C1qa expression in treated and untreated mice and observed a small but significant reduction of C1qa mRNA expression upon $\alpha \mathrm{IFN}-\gamma$ treatment $\left(t_{8.0}=2.33, p=0.048\right)$.

\section{Discussion}

In this study, we investigated if $T$. gondii infection-induced chronic neuroinflammation can be modulated by a consecutive intestinal infection with $H$. polygyrus. Our findings suggest that an acute nematode infection resulted in enhanced $T$. gondii removal, though at the same time exacerbated the inflammation-related decrease of gene expression of synapse-associated proteins.

Co-infection of $T$. gondii-infected mice with $H$. polygyrus was associated with a significant increase of the Th1-type response, whereas the IL-4 associated Th2 response was comparably suppressed in the brains of coinfected mice. The positive effect of IL- 4 in the generation of Th1-mediated immunity in the periphery has been previously acknowledged [77, 78]. The reason for this regulation is that CD8 T cell-derived IL-4 is responsible for maturation of dendritic cells that in turn accelerate Th1 immune responses [79]. Previous studies have shown that $H$. polygyrus infection was able to impede the $T$. gondii-associated Th1 response; however, in those experiments, the nematode was applied prior to $T$. gondii infection $[60,80]$. Moreover, we have previously reported that co-infection of mice with $T$. gondii and a nematode did not alter the course of Th1 infection in the gut, but we had used a high dose of $T$. gondii to induce ileitis and mice succumbed in the acute phase of the infection [81]. We have recently reported, using a similar experimental setup, that polarization of peripheral $\mathrm{CD}^{+} \mathrm{T}$ cells was disturbed in mice previously infected with $T$. gondii and later co-infected with $H$. polygyrus [82]. Of note, $T$. gondii infection did not prevent $H$. polygyrus-specific priming of $\mathrm{T}$ cells, but only the polarization to a Th2 phenotype, as H. polygyrus-reactive $\mathrm{CD}^{+}{ }^{+} \mathrm{T}$ cells upregulated T-bet expression (a Th1 transcription factor that controls IFN- $\gamma$ expression) and IFN- $\gamma$ production. The T cells that specifically recognized $H$. polygyrus antigens nevertheless responded in a similar way as Th1 T. gondii-specific CD $4^{+}$ $\mathrm{T}$ cells [82]. This may explain the reduction of parasite burden and increase in nematode fecundity in the co-infected animals. Immune cells responding to $H$. polygyrus, continuously present in the intestine, exhibit Th1 effector functions and further direct circulating immune cells towards a Th1 fate. Our current results align with this hypothesis. We found recruited $\mathrm{CD}_{4}^{+}, \mathrm{CD}^{+}$, and mononuclear cells with significant increases of the proportion of cells exhibiting Th1 effector function as determined by IFN- $\gamma$, iNOS, and IL-12 expression. In line with our results, $\mathrm{T}$ cells exhibiting a plastic Th1/Th2 shift have also been shown in a helminth/plasmodium co-infection model [64]. H. polygyrus-primed cells adoptively transferred into Plasmodium chabaudi-infected animals were converted to IFN- $\gamma$-producing cells and subsequently decreased in parasitemia. Future studies should investigate which immune cells mediate the decrease in parasite burden and whether they are $T$. gondii or $H$. polygyrusspecific.

Under homeostatic conditions, distinct cytokines exert a fine-tuned modulatory influence on learning, memory, and synaptic transmission in the CNS. During an infection, increased production of pro-inflammatory cytokines can disrupt the balance of neuro-immune interactions and lead to detrimental effects on neural plasticity and memory as well as neurogenesis and neuronal survival [83]. Pathologically increased levels of IL-1 $\beta$ and TNF can induce degeneration of neurons, alter synaptic scaling, and lead to hyperexcitability, which impairs motor and cognitive performance $[7,8,84]$. Along the same line, nitric oxide (NO) released from activated microglia via iNOS inhibits neuronal respiration that results in glutamate release, the principal excitatory neurotransmitter [85]. NO can also block the presynaptic reuptake of glutamate [86, 87] thereby leading to excitotoxicity and ultimately neurodegeneration. Consistently, in our present setting, co-infected mice exhibited a significant increase of microglia, myeloid cells, and $\mathrm{T}$ cells producing iNOS, IL-12, TNF, and IFN- $\gamma$, as well as an increase in gene expression of pro-inflammatory proteins IFN- $\gamma$, TNF IL-6, IL-1 $\beta$, and iNOS. Previous studies have convergingly shown that $T$. gondii infection-induced neuroinflammation is associated with markedly reduced expression of key synaptic proteins, including EAAT2, PSD-95, or Shank3 [34, 35], which may lead to increased extracellular glutamate levels and resulting excitotoxicity 
[73]. Correspondingly, in the present study, both T. gondiiinfected and co-infected mice displayed a significant decrease in gene expression of synaptic markers synaptophysin, PSD-95, BDNF, EAAT2, and GABA $_{A} \alpha 1$. Notably, expression of glutamate transporter EAAT2 and GABA-A receptor subunit $G_{A B A} \alpha 1$ were further significantly reduced in co-infected mice compared to mice infected with T. gondii only. With EAAT2 being critical for clearance of extracellular glutamate from the synaptic cleft and $\mathrm{GABA}_{\mathrm{A}} \alpha 1$ being a key component of inhibitory GABAergic signaling, their conjoint downregulation is likely to shift the delicate excitation-inhibition balance towards excitation, thereby promoting excitotoxicity (see also [73]). Of note, it is difficult to deduce the loss of synaptic integrity from gene expression alone. For example, Brooks et al. described altered GABAergic signaling in T. gondii infection [88]. Specifically, they found that the infection led to a loss of synaptic clustering of the GABA-synthesizing enzyme glutamate decarboxylase 67 (GAD67) in infected animals, resulting in a more diffuse localization throughout the neuropil. Changes in synaptic protein function were not always reflected by altered gene expression. We have previously reported a more detailed record of $T$. gondii-related changes of synaptic biochemistry at the protein level [35], and the present results add to those observations by demonstrating an aggravating effect on synaptic alterations by an acute inflammation induced by the nematode co-infection. There was an exacerbation of neuroinflammation upon co-infection that reduced gene expression of synaptic proteins further compared to animals infected with $T$. gondii only, potentially leaving mice more prone to excitotoxicity and neurodegenerative states.

To test whether the observed changes in neuronal gene expression were induced by the $T$. gondii-induced inflammatory milieu, we treated mice with sulfadiazine, which eliminates extracellular parasites, thus indirectly alleviating inflammatory responses [35]. Remarkably, the resulting reduction of neuroinflammation was associated with an attenuated decrease in gene expression of synaptic-associated proteins, supporting the hypothesis that the inflammatory response is responsible for the neuronal alterations.

Given the increased gene expression of IFN- $\gamma$ in infected animals and its functions in the immune response to $T$. gondii, we hypothesized that antagonizing IFN- $\gamma$ signaling would help to clarify the cause of the changes in gene expression of synapse-associated proteins. Consistent with the hypothesis that the specific inflammatory milieu was responsible for reduced synaptic gene expression, neutralizing IFN- $\gamma$ resulted in a partial rescue of the synaptic gene expression loss. The gene expression levels of synaptic proteins previously shown to be downregulated in $T$. gondii-infected animals, such as EAAT2 and
$\mathrm{GABA}_{\mathrm{A}} \alpha 1[73,88]$, were significantly higher when animals were treated with an antibody directed against IFN- $\gamma$. It was recently demonstrated that priming of microglia with IFN- $\gamma$ induced activation, MHC II upregulation, followed concomitant iNOS production responsible for neuronal network dysfunction involving inhibitory interneurons [89]. In our experiments we also detected IFN- $\gamma$ associated MHC II, iNOS, and IL-12 upregulation in isolated microglia cells and in recruited monocytes. Moreover, increased expression of EAAT2 and $\mathrm{GABA}_{\mathrm{A}} \alpha 1$, as key components in the excitation/inhibition balance, was associated with reduced IFN- $\gamma$ and iNOS levels pointing towards a possible mechanism for their regulation.

To further elucidate the underlying molecular mechanisms that might be responsible for the immune response-related neuronal alterations, we focused on cells with phagocytic capacity. Under normal homeostatic conditions, microglia have been shown to engulf neural progenitor cells and synapses. This phagocytic activity is often induced upon release of intracellular molecules (e.g., ATP) or tagging via the complement system [5]. Microglial-mediated phagocytosis of synapses depends on surface receptors recognizing their ligand. Triggering receptor expressed on myeloid cells 2 (TREM2) is a microglial receptor that mediates phagocytosis apoptotic cell debris and developmental synaptic pruning [90]. Similarly, CD36, a scavenger receptor on microglia and infiltrating monocytes, will recognize host and pathogen-derived molecules leading to upregulation of inflammatory molecules (i.e., iNOS and Nox-2) [91]. Both CD36 and TREM2 are understood to be neuroprotective; however, in pathological conditions like neuroinflammation, these have been associated with neurodegenerative diseases such as AD [65, 92, 93]. Therefore, we characterized gene expression of phagocytic markers associated with synaptic pruning such as CD36, TREM2, and C1qa. Our results showed a significant increase in pro-inflammatory cytokine production indicative of prolonged CNS neuro-immune activity. Furthermore, we observed a significant reduction of CD36, TREM2, and C1qa upon IFN- $\gamma$ neutralization in co-infected mice, suggesting prolonged presence of activated phagocytes and pro-inflammatory cytokines is contributing to the loss of synaptic gene expression. Future studies should dissect the involvement and phagocytic capacity of resident and recruited immune cells that alter synapses. It should be noted that mice in complete lack of IFN- $\gamma$ rapidly succumb to $T$. gondii infection $[28,94]$, and we thus reduced IFN- $\gamma$ levels only partially when applying the neutralizing antibody. Accordingly, the reduction of CD36, TREM2, and C1qa expression was 
also incomplete with the genes still being expressed, albeit at significantly lower levels. Therefore, we cannot conclusively state whether the partial recovery of synaptic gene expression in $T$. gondii-infected and coinfected mice treated with the IFN- $\gamma$ antibody was due to inflammatory activity induced by remaining low levels of IFN- $\gamma$, due to other proinflammatory cytokines, or due to definite effects of the parasite itself. Thus, subtle alterations of neural function induced by prolonged low-grade inflammation should not be ignored. Even post-pathogen elimination, adverse effects induced by neuroinflammation may manifest as neuronal and behavioral alterations or cognitive impairment [95-99]. Accordingly, it is likely that multiple mechanisms are involved in synaptic gene expression changes; nevertheless, the critical involvement of IFN- $\gamma$ was revealed.

\section{Conclusion}

Taken together, our data suggest that a neuroinflammatory response to $T$. gondii can be modulated by a strictly enteric helminth co-infection. While consecutive $H$. polygyrus co-infection promoted elimination of $T$. gondii, it adversely affected neural function and synapse-associated gene expression in an IFN- $\gamma$ dependent fashion. Helminth immunotherapy has to some extent proven to be successful in chronic inflammatory diseases such as autoimmune disorders or allergies [44, 46, 54, 55]. Regarding potential clinical implications, $T$. gondii seropositive individuals may be at risk for developing neuropsychiatric disorders [18, 100-102]; thus, future research should assess to what extent this risk may be further aggravated by manipulation of the peripheral inflammation [83].

\section{Additional file}

Additional file 1: Figure S1. Reduced IL-4 and IL-13 gene expression in the spleen of co-infected mice. (A-B) GRT-PCR data for relative expression of mRNA in the spleen homogenate from non-infected (Non.Inf.), $T$. gondii-infected $(\mathrm{Tg}), \mathrm{T}$. gondii and $\mathrm{H}$. polygyrus co-infected $(\mathrm{Tg}+\mathrm{Hp})$, and $\mathrm{H}$. polygyrus-infected $(\mathrm{Hp})$ mice. Relative mRNA levels were normalized to the mean of the non-infected control group (Non.Inf). Bars represent mean \pm SEM. (PDF $33 \mathrm{~kb})$

\footnotetext{
Abbreviations

AD: Alzheimer' disease; ALS: Amyotrophic lateral sclerosis; Arg: Arginase; BDNF: Brain-derived neurotrophic factor; CD: Cluster domain; CNS: Central nervous system; EAAT2: Excitatory amino acid transporter 2;

FACS: Fluorescence-activated cell sorting; GABA: Gamma-aminobutyric acid; Hp: Heligmosomoides polygyrus; IFN: Interferon; IL: Interleukin; iNOS: Inducible nitric oxide synthase; MHC: Major histocompatibility complex; MS: Multiple sclerosis; PD: Parkinson's disease; PSD-95: Postsynaptic density protein 95; Tg: Toxoplasma gondii; Th1/Th2: Type 1/type 2; TNF: Tumor necrosis factor; TREM2: Triggering receptor expressed on myeloid cells 2
}

\section{Acknowledgements}

We thank Dr. Abidat Schneider, Petra Grüneberg, and Dana Zabler for their excellent technical assistance. The authors thank the Deutsches Rheuma-Forschungszentrum (DRFZ) for providing experimental materials.

\section{Authors' contributions}

TF performed and AB, HD, JS, and NA helped with experiments. IRD conceptualized and designed the research/experiments. TF and IRD wrote the manuscript. BS performed statistical analysis and edited the manuscript. $\mathrm{SH}$ provided materials for the research. TS provided data interpretation. All authors approved the final version of the manuscript.

\section{Funding}

The project was funded by SFB 854 TP 25 to IRD, the federal state Saxony-Anhalt, and the European Structural and Investment Funds (ESF, 2014-2020; project number ZS/2016/08/80645 to IRD and BS), the Leibniz Association (LIN Special Project to IRD and BS), and GRK 2046 to SH.

\section{Availability of data and materials}

The datasets used and/or analyzed during the current study are available from the corresponding author on reasonable request.

\section{Ethics approval and consent to participate}

All animal experiments were approved by the respective authorities (Landesverwaltungsamt Halle, Sachsen-Anhalt, Germany) in accordance with the German and European legislation.

\section{Consent for publication}

Not applicable.

\section{Competing interests}

The authors declare that they have no competing interests.

\section{Author details}

'Institute of Inflammation and Neurodegeneration, Medizinische Fakultät, Otto-von-Guericke-University Magdeburg, Leipziger Straße 44, 39120 Magdeburg, Germany. ${ }^{2}$ Institute of Molecular and Clinical Immunology, Otto-von-Guericke-University Magdeburg, Magdeburg, Germany. ${ }^{3}$ Department of Veterinary Medicine, Institute of Immunology, Free University Berlin, Berlin, Germany. ${ }^{4}$ Leibniz Institute of Neurobiology, Magdeburg, Germany. ${ }^{5}$ Center for Behavioral Brain Sciences, Magdeburg, Germany.

${ }^{6}$ Department of Psychiatry and Psychotherapy, University Medicine Göttingen, Göttingen, Germany.

Received: 27 March 2019 Accepted: 9 July 2019

Published online: 29 July 2019

\section{References}

1. Hendriks JJA, Teunissen CE, de Vries HE, Dijkstra CD. Macrophages and neurodegeneration. Brain Res Brain Res Rev. 2005;48:185-95. https://doi. org/10.1016/.brainresrev.2004.12.008.

2. Muldoon LL, Alvarez JI, Begley DJ, Boado RJ, Del Zoppo GJ, Doolittle $N D$, et al. Immunologic privilege in the central nervous system and the blood-brain barrier. J Cereb Blood Flow Metab. 2013;33:13-21. https:// doi.org/10.1038/jcbfm.2012.153.

3. Levin MC, Lee SM, Kalume F, Morcos Y, Jr FCD, Hasty KA, et al. Autoimmunity due to molecular mimicry as a cause of neurological disease. Nat Med. 2002;8:509. https://doi.org/10.1038/nm0502-509.

4. Schwartz M, Baruch K. The resolution of neuroinflammation in neurodegeneration: leukocyte recruitment via the choroid plexus. EMBO J. 2014;33:7-22. https://doi.org/10.1002/embj.201386609.

5. Norris GT, Kipnis J. Immune cells and CNS physiology: microglia and beyond. J Exp Med. 2019;216:60-70. https://doi.org/10.1084/jem.20180199.

6. Filiano AJ, Xu Y, Tustison NJ, Marsh RL, Baker W, Smirnov I, et al. Unexpected role of interferon- $\gamma$ in regulating neuronal connectivity and social behaviour. Nature. 2016;535:425. https://doi.org/10.1038/nature18626.

7. Stojakovic A, Paz-Filho G, Arcos-Burgos M, Licinio J, Wong M-L, Mastronardi CA. Role of the IL-1 pathway in dopaminergic neurodegeneration and decreased voluntary movement. Mol Neurobiol. 2017;54:4486-95. https:// doi.org/10.1007/s12035-016-9988-x. 
8. Habbas S, Santello M, Becker D, Stubbe H, Zappia G, Liaudet N, et al Neuroinflammatory TNFa impairs memory via astrocyte signaling. Cell. 2015; 163:1730-41. https://doi.org/10.1016/j.cell.2015.11.023.

9. Derecki NC, Cardani AN, Yang CH, Quinnies KM, Crihfield A, Lynch KR, Kipnis J. Regulation of learning and memory by meningeal immunity: a key role for IL-4. J Exp Med. 2010;207:1067-80. https://doi.org/10.1084/jem.20091419.

10. Kuhn SA, van Landeghem FKH, Zacharias R, Färber K, Rappert A, Pavlovic S, et al. Microglia express $G A B A(B)$ receptors to modulate interleukin release. Mol Cell Neurosci. 2004;25:312-22. https://doi.org/10.1016/j.mcn.2003.10.023.

11. Färber K, Pannasch U, Kettenmann H. Dopamine and noradrenaline control distinct functions in rodent microglial cells. Mol Cell Neurosci. 2005;29:128-38. https://doi.org/10.1016/j.mcn.2005.01.003.

12. Bhandage AK, Kanatani S, Barragan A. Toxoplasma-induced hypermigration of primary cortical microglia implicates GABAergic signaling. Front Cell Infect Microbiol. 2019:9:73. https://doi.org/10.3389/fcimb.2019.00073.

13. Noda M, Nakanishi H, Nabekura J, Akaike N. AMPA-kainate subtypes of glutamate receptor in rat cerebral microglia. J Neurosci. 2000;20:251-8. https://doi.org/10.1523/JNEUROSCI.20-01-00251.2000.

14. Blasko I, Stampfer-Kountchev M, Robatscher P, Veerhuis R, Eikelenboom P, Grubeck-Loebenstein B. How chronic inflammation can affect the brain and support the development of Alzheimer's disease in old age: the role of microglia and astrocytes. Aging Cell. 2004;3:169-76. https://doi.org/10.1111/ j.1474-9728.2004.00101.x

15. Kim YS, Joh TH. Microglia, major player in the brain inflammation: their roles in the pathogenesis of Parkinson's disease. Exp Mol Med. 2006;38:333. https://doi.org/10.1038/emm.2006.40.

16. Papadimitriou D, Le Verche $V$, Jacquier A, Ikiz B, Przedborski S, Re DB. Inflammation in ALS and SMA: sorting out the good from the evil. Neurobiol Dis. 2010;37:493-502. https://doi.org/10.1016/j.nbd.2009.10.005.

17. Frischer JM, Bramow S, Dal-Bianco A, Lucchinetti CF, Rauschka H, Schmidbauer $\mathrm{M}$, et al. The relation between inflammation and neurodegeneration in multiple sclerosis brains. Brain. 2009;132:1175-89. https://doi.org/10.1093/brain/awp070.

18. Burgdorf KS, Trabjerg BB, Pedersen MG, Nissen J, Banasik K, Pedersen OB, et al. Large-scale study of Toxoplasma and Cytomegalovirus shows an association between infection and serious psychiatric disorders. Brain Behav Immun. 2019. https://doi.org/10.1016/j.bbi.2019.01.026.

19. Parlog A, Schlüter D, Dunay IR. Toxoplasma gondii-induced neuronal alterations. Parasite Immunol. 2015;37:159-70. https://doi.org/10.1111/pim.12157.

20. Weiss LM, Dubey JP. Toxoplasmosis: a history of clinical observations. Int J Parasitol. 2009;39:895-901. https://doi.org/10.1016/j.jpara.2009.02.004.

21. Hermes G, Ajioka JW, Kelly KA, Mui E, Roberts F, Kasza K, et al. Neurological and behavioral abnormalities, ventricular dilatation, altered cellular functions, inflammation, and neuronal injury in brains of mice due to common, persistent, parasitic infection. J Neuroinflammation. 2008;5:48. https://doi.org/10.1186/1742-2094-5-48.

22. Blanchard N, Dunay IR, Schlüter D. Persistence of Toxoplasma gondii in the central nervous system: a fine-tuned balance between the parasite, the brain and the immune system. Parasite Immunol. 2015;37:150-8. https://doi. org/10.1111/pim.12173

23. Biswas A, Bruder D, Wolf SA, Jeron A, Mack M, Heimesaat MM, Dunay IR. Ly6Chigh monocytes control cerebral toxoplasmosis. J Immunol. 2015; 1402037. https://doi.org/10.4049/jimmunol.1402037.

24. Biswas A, French T, Düsedau HP, Mueller N, Riek-Burchardt M, Dudeck A, et al. Behavior of neutrophil granulocytes during toxoplasma gondii infection in the central nervous system. Front Cell Infect Microbiol. 2017;7:259. https://doi.org/10.3389/fcimb.2017.00259.

25. Feliu V, Vasseur V, Grover HS, Chu HH, Brown MJ, Wang J, et al. Location of the CD8 T cell epitope within the antigenic precursor determines immunogenicity and protection against the Toxoplasma gondii parasite. PLoS Pathog. 2013;9:e1003449. https://doi.org/10.1371/journal.ppat.1003449.

26. Klose CSN, Flach M, Möhle L, Rogell L, Hoyler T, Ebert K, et al. Differentiation of type $1 \mathrm{ILCS}$ from a common progenitor to all helper-like innate lymphoid cell lineages. Cell. 2014;157:340-56. https://doi.org/10.1016/j.cell.2014.03.030.

27. Dunay IR, Diefenbach A. Group 1 innate lymphoid cells in Toxoplasma gondii infection. Parasite Immunol. 2018. https://doi.org/10.1111/pim.12516.

28. Pittman KJ, Knoll LJ. Long-term relationships: the complicated interplay between the host and the developmental stages of Toxoplasma gondii during acute and chronic infections. Microbiol Mol Biol Rev. 2015;79: 387-401. https://doi.org/10.1128/MMBR.00027-15.
29. Vyas A, Kim S-K, Giacomini N, Boothroyd JC, Sapolsky RM. Behaviora changes induced by Toxoplasma infection of rodents are highly specific to aversion of cat odors. PNAS. 2007;104:6442-7. https://doi.org/10.1073/pnas. 0608310104.

30. Alvarado-Esquivel C, Rico-Almochantaf YDR, Hernández-Tinoco J, Quiñones-Canales G, Sánchez-Anguiano LF, Torres-González J, et al. Toxoplasma gondii exposure and neurological disorders: an age- and gender-matched case-control pilot study. Eur J Microbiol Immunol (Bp). 2017;7:303-9. https://doi.org/10.1556/1886.2017.00033.

31. Miman O, Kusbeci OY, Aktepe OC, Cetinkaya Z. The probable relation between Toxoplasma gondii and Parkinson's disease. Neurosci Lett. 2010; 475:129-31. https://doi.org/10.1016/j.neulet.2010.03.057.

32. Kusbeci OY, Miman O, Yaman M, Aktepe OC, Yazar S. Could Toxoplasma gondii have any role in Alzheimer disease? Alzheimer Dis Assoc Disord. 2011:25:1-3. https://doi.org/10.1097/WAD.0b013e3181f73bc2.

33. Torrey EF, Yolken RH. Toxoplasma gondii and schizophrenia. Emerg Infect Dis. 2003:9:1375-80. https://doi.org/10.3201/eid0911.030143.

34. Parlog A, Harsan L-A, Zagrebelsky M, Weller M, von Elverfeldt D, Mawrin C, et al. Chronic murine toxoplasmosis is defined by subtle changes in neuronal connectivity. Dis Model Mech. 2014;7:459-69. https://doi.org/1 $0.1242 / \mathrm{dmm} .014183$

35. Lang D, Schott BH, van Ham M, Morton L, Kulikovskaja L, Herrera-Molina R, et al. Chronic Toxoplasma infection is associated with distinct alterations in the synaptic protein composition. J Neuroinflammation. 2018. https://doi. org/10.1186/s12974-018-1242-1.

36. Bollet AJ, Black R, Bunim JJ. Major undesirable side-effects resulting from prednisolone and prednisone. JAMA. 1955;158:459-63. https://doi.org/10.1 001/jama.1955.02960060017005.

37. Langer-Gould A, Moses HH, Murray TJ. Strategies for managing the side effects of treatments for multiple sclerosis. Neurology. 2004;63:S35-41. https://doi.org/10.1212/WNL.63.11_suppl_5.S35.

38. Mills J. Pneumocystis carinii and Toxoplasma gondii infections in patients with AIDS. Rev Infect Dis. 1986;8:1001-11. https://doi.org/10.1 093/clinids/8.6.1001.

39. Dunay IR, Gajurel K, Dhakal R, Liesenfeld O, Montoya JG. Treatment of toxoplasmosis: historical perspective, animal models, and current clinical practice. Clin Microbiol Rev. 2018;31:e00057-17. https://doi.org/10.1128/ CMR.00057-17.

40. Weber MS, Hohlfeld R, Zamvil SS. Mechanism of action of glatiramer acetate in treatment of multiple sclerosis. Neurotherapeutics. 2007:4:647-53. https:// doi.org/10.1016/j.nurt.2007.08.002.

41. Baruch K, Deczkowska A, Rosenzweig N, Tsitsou-Kampeli A, Sharif AM, Matcovitch-Natan O, et al. PD-1 immune checkpoint blockade reduces pathology and improves memory in mouse models of Alzheimer's disease. Nat Med. 2016:22:135. https://doi.org/10.1038/nm.4022.

42. Schwab N, Schneider-Hohendorf T, Wiendl H. Therapeutic uses of antia4-integrin (anti-VLA-4) antibodies in multiple sclerosis. Int Immunol. 2015;27:47-53. https://doi.org/10.1093/intimm/dxu096.

43. Eichenberger RM, Ryan S, Jones L, Buitrago G, Polster R, Montes de Oca M, et al. Hookworm secreted extracellular vesicles interact with host cells and prevent inducible colitis in mice. Front Immunol. 2018;9:850. https://doi. org/10.3389/fimmu.2018.00850.

44. Terrazas C, de Dios Ruiz-Rosado J, Amici SA, Jablonski KA, Martinez-Saucedo D, Webb LM, et al. Helminth-induced Ly6C(hi) monocyte-derived alternatively activated macrophages suppress experimental autoimmune encephalomyelitis. Sci Rep. 2017;7:40814. https://doi.org/10.1038/srep40814.

45. McSorley HJ, Hewitson JP, Maizels RM. Immunomodulation by helminth parasites: defining mechanisms and mediators. Int J Parasitol. 2013;43: 301-10. https://doi.org/10.1016/j.ijpara.2012.11.011.

46. Weinstock JV, Elliott DE. Translatability of helminth therapy in inflammatory bowe diseases. Int J Parasitol. 2013:43:245-51. https://doi.org/10.1016/j.jpara.2012.10.016.

47. Whelan RA, Rausch S, Ebner F, Günzel D, Richter JF, Hering NA, et al. A transgenic probiotic secreting a parasite immunomodulator for site-directed treatment of gut inflammation. Mol Ther. 2014;22:1730-40. https://doi.org/1 0.1038/mt.2014.125.

48. Fleming JO, Isaak A, Lee JE, Luzzio CC, Carrithers MD, Cook TD, et al. Probiotic helminth administration in relapsing-remitting multiple sclerosis: a phase 1 study. Mult Scler. 2011;17:743-54. https://doi.org/10.1177/135245 8511398054.

49. Fleming J, Hernandez G, Hartman L, Maksimovic J, Nace S, Lawler B, et al. Safety and efficacy of helminth treatment in relapsing-remitting multiple 
sclerosis: results of the HINT 2 clinical trial. Mult Scler. 2019;25:81-91. https:// doi.org/10.1177/1352458517736377.

50. Maizels RM, Smits HH, McSorley HJ. Modulation of host immunity by helminths: the expanding repertoire of parasite effector molecules. Immunity. 2018;49:801-18. https://doi.org/10.1016/j.immuni.2018.10.016.

51. Schnoeller C, Rausch S, Pillai S, Avagyan A, Wittig BM, Loddenkemper C, et al. A helminth immunomodulator reduces allergic and inflammatory responses by induction of IL-10-producing macrophages. J Immunol. 2008; 180:4265-72. https://doi.org/10.4049/jimmunol.180.6.4265.

52. Ebner F, Hepworth MR, Rausch S, Janek K, Niewienda A, Kühl A, et al. Therapeutic potential of larval excretory/secretory proteins of the pig whipworm Trichuris suis in allergic disease. Allergy. 2014;69:1489-97. https:// doi.org/10.1111/all.12496.

53. Ziegler T, Rausch S, Steinfelder S, Klotz C, Hepworth MR, Kühl AA, et al. A novel regulatory macrophage induced by a helminth molecule instructs IL-10 in CD4+ T cells and protects against mucosal inflammation. J Immunol. 2015;194:1555-64. https://doi.org/10.4049/ jimmunol.1401217.

54. Pineda MA, Al-Riyami L, Harnett W, Harnett MM. Lessons from helminth infections: ES-62 highlights new interventional approaches in rheumatoid arthritis. Clin Exp Immunol. 2014;177:13-23. https://doi.org/10.1111/cei.12252.

55. Saunders KA, Raine T, Cooke A, Lawrence CE. Inhibition of autoimmune type 1 diabetes by gastrointestinal helminth infection. Infect Immun. 2007; 75:397-407. https://doi.org/10.1128/AAl.00664-06.

56. Smallwood TB, Giacomin PR, Loukas A, Mulvenna JP, Clark RJ, Miles JJ. Helminth immunomodulation in autoimmune disease. Front Immunol. 2017;8:453. https://doi.org/10.3389/fimmu.2017.00453.

57. Klotz C, Ziegler T, Figueiredo AS, Rausch S, Hepworth MR, Obsivac N, et al. A helminth immunomodulator exploits host signaling events to regulate cytokine production in macrophages. PLoS Pathog. 2011;7:e1001248. https://doi.org/10.1371/journal.ppat.1001248.

58. Helmby H. Human helminth therapy to treat inflammatory disorders where do we stand? BMC Immunol. 2015;16:12. https://doi.org/10.1186/s12 865-015-0074-3.

59. Kahl J, Brattig N, Liebau E. The untapped pharmacopeic potential of helminths. Trends Parasitol. 2018;34:828-42. https://doi.org/10.1016/j.pt.2 018.05.011.

60. Khan IA, Hakak R, Eberle K, Sayles P, Weiss LM, Urban JF. Coinfection with Heligmosomoides polygyrus fails to establish CD8+ T-cell immunity against Toxoplasma gondii. Infect Immun. 2008;76:1305-13. https://doi.org/10.1128/ |Al.01236-07.

61. Reynolds LA, Filbey KJ, Maizels RM. Immunity to the model intestinal helminth parasite Heligmosomoides polygyrus. Semin Immunopathol. 2012; 34:829-46. https://doi.org/10.1007/s00281-012-0347-3.

62. Rausch S, Huehn J, Kirchhoff D, Rzepecka J, Schnoeller C, Pillai S, et al. Functional analysis of effector and regulatory $T$ cells in a parasitic nematode infection. Infect Immun. 2008;76:1908-19. https://doi.org/10.1128//Al.01233-07.

63. Dunay IR, Heimesaat MM, Bushrab FN, Müller RH, Stocker H, Arasteh K, et al. Atovaquone maintenance therapy prevents reactivation of toxoplasmic encephalitis in a murine model of reactivated toxoplasmosis. Antimicrob Agents Chemother. 2004;48:4848-54. https:// doi.org/10.1128/AAC.48.12.4848-4854.2004.

64. Coomes SM, Pelly VS, Kannan Y, Okoye IS, Czieso S, Entwistle L, et al. IFNY and IL-12 restrict Th2 responses during helminth/plasmodium co-infection and promote IFNy from Th2 cells. PLoS Pathog. 2015;11:e1004994. https:// doi.org/10.1371/journal.ppat.1004994.

65. Möhle L, Israel N, Paarmann K, Krohn M, Pietkiewicz S, Müller A, et al. Chronic Toxoplasma gondii infection enhances $\beta$-amyloid phagocytosis and clearance by recruited monocytes. Acta Neuropathol Commun. 2016;4:25. https://doi.org/10.1186/s40478-016-0293-8

66. Düsedau HP, Kleveman J, Figueiredo CA, Biswas A, Steffen J, Kliche S, et al. p75NTR regulates brain mononuclear cell function and neuronal structure in Toxoplasma infection-induced neuroinflammation. Glia. 2019;67:193-211. https://doi.org/10.1002/glia.23553.

67. Bereswill S, Kühl AA, Alutis M, Fischer A, Möhle L, Struck D, et al. The impact of Toll-like-receptor-9 on intestinal microbiota composition and extraintestinal sequelae in experimental Toxoplasma gondii induced ileitis. Gut Pathog. 2014;6:19. https://doi.org/10.1186/1757-4749-6-19.

68. Möhle L, Parlog A, Pahnke J, Dunay IR. Spinal cord pathology in chronic experimental Toxoplasma gondii infection. Eur J Microbiol Immunol (Bp). 2014;4:65-75. https://doi.org/10.1556/EuJMI.4.2014.1.6.
69. Yap G, Pesin M, Sher A. Cutting edge: $\mathrm{LL}-12$ is required for the maintenance of IFN- $\gamma$ production in T cells mediating chronic resistance to the intracellular pathogen, Toxoplasma gondii. J Immunol. 2000;165:628-31. https://doi.org/10.4049/jimmunol.165.2.628.

70. Melo MB, Jensen KDC, Saeij JPJ. Toxoplasma gondii effectors are master regulators of the inflammatory response. Trends Parasitol. 2011;27:487-95. https://doi.org/10.1016/.jpt.2011.08.001.

71. Murray PJ. Macrophages as a battleground for toxoplasma pathogenesis. Cell Host Microbe. 2011;9:445-7. https://doi.org/10.1016/j.chom.2011.05.010.

72. Cossarizza A, Chang H-D, Radbruch A, Akdis M, Andrä I, Annunziato F, et al. Guidelines for the use of flow cytometry and cell sorting in immunological studies. Eur J Immunol. 2017;47:1584-797. https://doi. org/10.1002/eji.201646632.

73. David CN, Frias ES, Szu JI, Vieira PA, Hubbard JA, Lovelace J, et al. GLT-1-dependent disruption of CNS glutamate homeostasis and neuronal function by the protozoan parasite Toxoplasma gondii. PLoS Pathog. 2016;12:e1005643. https://doi.org/10.1371/journal.ppat.1005643.

74. Itoh N, Enomoto A, Nagai T, Takahashi M, Yamada K. Molecular mechanism linking BDNF/TrkB signaling with the NMDA receptor in memory: the role of Girdin in the CNS. Rev Neurosci. 2016;27:481-90. https://doi.org/10.1515/ revneuro-2015-0072

75. Bekinschtein P, Cammarota M, Medina JH. BDNF and memory processing. Neuropharmacology. 2014;76(Pt C):677-83. https://doi.org/10.1016/j. neuropharm.2013.04.024

76. Montoya JG, Liesenfeld O. Toxoplasmosis. Lancet. 2004;363:1965-76. https:// doi.org/10.1016/S0140-6736(04)16412-X.

77. Schüler T, Qin Z, Ibe S, Noben-Trauth N, Blankenstein T. T helper cell type 1-associated and cytotoxic T lymphocyte-mediated tumor immunity is impaired in interleukin 4-deficient mice. J Exp Med. 1999; 189:803-10. https://doi.org/10.1084/jem.189.5.803.

78. Mencacci A, Del Sero G, Cenci E, d'Ostiani CF, Bacci A, Montagnoli C, et al. Endogenous interleukin 4 is required for development of protective CD4+ T helper type 1 cell responses to Candida albicans. J Exp Med. 1998;187:307-17. https://doi.org/10.1084/jem.187.3.307.

79. Schüler T, Kammertoens T, Preiss S, Debs P, Noben-Trauth N, Blankenstein T. Generation of tumor-associated cytotoxic T lymphocytes requires interleukin 4 from CD8(+) T cells. J Exp Med. 2001;194:1767-75. https://doi.org/10.1084/ jem.194.12.1767.

80. Marple A, Wu W, Shah S, Zhao Y, Du P, Gause WC, Yap GS. Cutting edge: helminth coinfection blocks effector differentiation of CD8 T cells through alternate host Th2- and IL-10-mediated responses. J Immunol. 2017;198: 634-9. https://doi.org/10.4049/jimmunol.1601741.

81. Liesenfeld O, Dunay IR, Erb KJ. Infection with Toxoplasma gondii reduces established and developing Th2 responses induced by Nippostrongylus brasiliensis infection. Infect Immun. 2004;72:3812-22. https://doi.org/10.112 8/IAl.72.7.3812-3822.2004.

82. Ahmed N, French T, Rausch S, Kuhl A, Hemminger K, Dunay IR, et al. Toxoplasma co-infection prevents Th2 differentiation and leads to a helminth-specific Th1 response. Front Cell Infect Microbiol. 2017;7:341. https://doi.org/10.3389/fcimb.2017.00341.

83. Yirmiya R, Goshen I. Immune modulation of learning, memory, neural plasticity and neurogenesis. Brain Behav Immun. 2011;25:181-213. https:// doi.org/10.1016/j.bbi.2010.10.015.

84. Stellwagen D, Malenka RC. Synaptic scaling mediated by glial TNF-a. Nature. 2006:440:1054. https://doi.org/10.1038/nature04671.

85. Bal-Price A, Brown GC. Inflammatory neurodegeneration mediated by nitric oxide from activated glia-inhibiting neuronal respiration, causing glutamate release and excitotoxicity. J Neurosci. 2001;21:6480-91.

86. Maragakis NJ, Rothstein JD. Mechanisms of disease: astrocytes in neurodegenerative disease. Nat Rev Neurol. 2006;2:679. https://doi.org/10.1 038/ncpneuro0355.

87. Rao JS, Kellom M, Kim H-W, Rapoport SI, Reese EA. Neuroinflammation and synaptic loss. Neurochem Res. 2012;37:903-10. https://doi.org/10.1 007/s11064-012-0708-2.

88. Brooks JM, Carrillo GL, Su J, Lindsay DS, Fox MA, Blader IJ. Toxoplasma gondii infections alter GABAergic synapses and signaling in the central nervous system. MBio. 2015;6:e01428-15. https://doi.org/10.1128/mBio.01428-15.

89. Ta T-T, Dikmen HO, Schilling S, Chausse B, Lewen A, Hollnagel J-O, Kann O. Priming of microglia with IFN- $\gamma$ slows neuronal gamma oscillations in situ. Proc Natl Acad Sci U S A. 2019. https://doi.org/10.1 073/pnas.1813562116 
90. Filipello F, Morini R, Corradini I, Zerbi V, Canzi A, Michalski B, et al. The microglial innate immune receptor TREM2 is required for synapse elimination and normal brain connectivity. Immunity. 2018;48:979-991.e8. https://doi.org/10.1016/.jimmuni.2018.04.016.

91. Garcia-Bonilla L, Park L, ladecola C. Commentary on Myers et al.: Growing role of the innate immunity receptor CD36 in central nervous system diseases. Exp Neurol. 2014;261:633-7. https://doi.org/10.1016/j. expneurol.2014.08.016

92. Ulrich JD, Finn MB, Wang $Y$, Shen A, Mahan TE, Jiang $H$, et al. Altered microglial response to $A \beta$ plaques in APPPS1-21 mice heterozygous for TREM2. Mol Neurodegener. 2014;9:20. https://doi.org/10.1 186/1750-1326-9-20.

93. Hickman SE, Allison EK, El Khoury J. Microglial dysfunction and defective beta-amyloid clearance pathways in aging Alzheimer's disease mice. J Neurosci. 2008;28:8354-60. https://doi.org/10.1523/JNEUROSCI.0616-08.2008.

94. Suzuki Y, Orellana MA, Schreiber RD, Remington JS. Interferon-gamma: the major mediator of resistance against Toxoplasma gondii. Science. 1988;240: 516-8. https://doi.org/10.1126/science.3128869.

95. Klein RS, Garber C, Howard N. Infectious immunity in the central nervous system and brain function. Nat Immunol. 2017;18:132. https:// doi.org/10.1038/ni.3656.

96. Hamdani N, Daban-Huard C, Lajnef M, Gadel R, Le Corvoisier P, Delavest M, et al. Cognitive deterioration among bipolar disorder patients infected by Toxoplasma gondii is correlated to interleukin 6 levels. J Affect Disord. 2015; 179:161-6. https://doi.org/10.1016/j.jad.2015.03.038.

97. Wohlfert EA, Blader IJ, Wilson EH. Brains and brawn: toxoplasma infections of the central nervous system and skeletal muscle. Trends Parasitol. 2017;33: 519-31. https://doi.org/10.1016/j.pt.2017.04.001.

98. Ihara F, Nishimura M, Muroi Y, Mahmoud ME, Yokoyama N, Nagamune K, Nishikawa Y. Toxoplasma gondii infection in mice impairs long-term fear memory consolidation through dysfunction of the cortex and amygdala. Infect Immun. 2016;84:2861-70. https://doi.org/10.1128/IAI.00217-16.

99. Koshy AA, Dietrich HK, Christian DA, Melehani JH, Shastri AJ, Hunter CA, Boothroyd JC. Toxoplasma co-opts host cells it does not invade. PLoS Pathog. 2012;8:e1002825. https://doi.org/10.1371/journal.ppat.1002825.

100. Ngô HM, Zhou Y, Lorenzi H, Wang K, Kim T-K, Zhou Y, et al. Toxoplasma modulates signature pathways of human epilepsy, neurodegeneration \& cancer. Sci Rep. 2017:7:11496. https://doi.org/10.1038/s41598-017-10675-6.

101. Mendy A, Vieira ER, Albatineh AN, Gasana J. Immediate rather than delayed memory impairment in older adults with latent toxoplasmosis. Brain Behav Immun. 2015;45:36-40. https://doi.org/10.1016/j.bbi.2014.12.006.

102. Torrey EF, Bartko JJ, Yolken RH. Toxoplasma gondii and other risk factors for schizophrenia: an update. Schizophr Bull. 2012;38:642-7. https://doi.org/10.1 093/schbul/sbs043.

\section{Publisher's Note}

Springer Nature remains neutral with regard to jurisdictional claims in published maps and institutional affiliations.

Ready to submit your research? Choose BMC and benefit from:

- fast, convenient online submission

- thorough peer review by experienced researchers in your field

- rapid publication on acceptance

- support for research data, including large and complex data types

- gold Open Access which fosters wider collaboration and increased citations

- maximum visibility for your research: over $100 \mathrm{M}$ website views per year

At $\mathrm{BMC}$, research is always in progress.

Learn more biomedcentral.com/submissions 